\title{
Traditional Dwellings of GÖlde (INCESU): A Rural Heritage in the Process of Change
}

\section{Esra Eken \& F. Nurşen Kul}

To cite this article: Esra Eken \& F. Nurșen Kul (2021) Traditional Dwellings of GÖlde (INCESU):

A Rural Heritage in the Process of Change, Vernacular Architecture, 52:1, 41-62, DOI: 10.1080/03055477.2021.1981593

To link to this article: https://doi.org/10.1080/03055477.2021.1981593

\section{曲 Published online: 29 Nov 2021.}

Submit your article to this journal

Џ Article views: 154

Q View related articles $\sqsubset$

View Crossmark data $₫$ 


\title{
TRADITIONAL DWELLINGS OF GÖLDE (INCESU): A RURAL HERITAGE IN THE PROCESS OF CHANGE
}

\author{
Esra Eken ${ }^{a}$ (D) and F. Nurşen Kul $l^{b}$ \\ ${ }^{a}$ Department of Architecture, Middle East Technical University, Ankara, Turkey; ${ }^{\mathrm{b}}$ Department of Conservation and Restoration \\ of Cultural Heritage, Izmir Institute of Technology, Izmir, Turkey
}

Correspondence: Esra Eken, Üniversiteler, Dumlupınar Blv. 1/6 D:133, 06800 Çankaya/Ankara, Turkey esra.eken.06@gmail.com

Gölde, officially named Incesu, is a rural settlement located in Aegean Anatolia. Before the population exchange between Greece and Turkey in 1923, Gölde hosted both Orthodox Rum and Muslim Turkish communities. Despite out-migration since 1923, traditional life continued in the settlement with a small population that now comprises mostly elderly Turkish people. This paper aims to understand traditional Gölde dwelling units by analysing the influence of daily-life practices, customs, traditions and values through interviews with current locals and the oral testimonies of former Rum inhabitants. A site survey identified 136 traditional dwelling units, 68 of which are still inhabited. Site reconstruction analysis revealed the original condition of 90 dwelling units. These formed the primary focus of investigation. No major differences were found between houses originally belonging to the Rum and Turkish communities. However, the study identified significant adaptations of the dwelling units in line with changing socio-cultural conditions over time.

KEYwords: Gölde, rural architecture, adaptation, daily life, traditional dwelling

\section{INTRODUCTION}

Kula, a town in Manisa Province in Turkey's Aegean Region, is important for being one of the best-preserved examples of a nineteenth-century Ottoman town. The town serves as an open-air museum for those studying Anatolian vernacular architecture. It remains physically intact and in undamaged condition following the War of Independence which resulted in the destruction of various Anatolian towns. ${ }^{1}$ Travelling $7 \mathrm{~km}$ north from Cumhuriyet Street, which connects the İzmir-Ankara highway to Kula town centre, another intact settlement is encountered (Fig. 1). This is Gölde village, officially named Incesu today, which still carries traces of the once rich agricultural and economic life in its houses and public spaces. Before the population exchange that took place following the 1923 agreement between the governments of Greece and Turkey, Muslim Turks and Christian Orthodox Rums lived side by side in Gölde and together shaped the landscape and built environment. Today, it is an almost desolated place, with a population of 170 Turks, mostly elderly, who nevertheless retain the knowledge of their parents and grandparents about life in the village before the population exchange.

The Rum population in Western Anatolia came from the Aegean Islands in the nineteenth century. ${ }^{2}$
However, the presence of Rums in Gölde goes back much further than this. The earliest document containing information about Gölde Rums is an avarız register, dated $1676 .^{3}$ This means that Rums and Turks had lived side by side in Gölde for centuries. In fact, the travellers who visited Gölde in the nineteenth and early twentieth centuries mentioned that the Rums did not know Greek and, instead, spoke Turkish. Greek was used by only a few elderly Rum women. ${ }^{4}$ Kharalampos Khatzilampidis, a Rum immigrant who migrated from Gölde, explained that, although ceremonies in the church in Gölde were in Greek, most people could not understand what the priest was saying. The priest therefore read the Bible in both Greek and Turkish. ${ }^{5}$

These two communities shared a common life and peacefully coexisted in Gölde, as they did in many other places throughout the Ottoman lands. Yet, this peaceful environment became turbulent with the decline of the Ottoman Empire. Tensions between the Rums and Turks accelerated during the Balkan Wars and turned into a full conflict with the invasion of Anatolia by the Greek army in 1919. The invasion ended in 1922 with the victory of the Turkish army in the Great Offensive. Approximately 1,000,000 Greeks migrated to Greece during this period. ${ }^{6}$ The narratives of Turks in Gölde reveal that the Gölde Rums left the settlement during the war. ${ }^{7}$ The remaining Rums of Anatolia, on the other hand, left their homelands in line with the population exchange. ${ }^{8}$ 


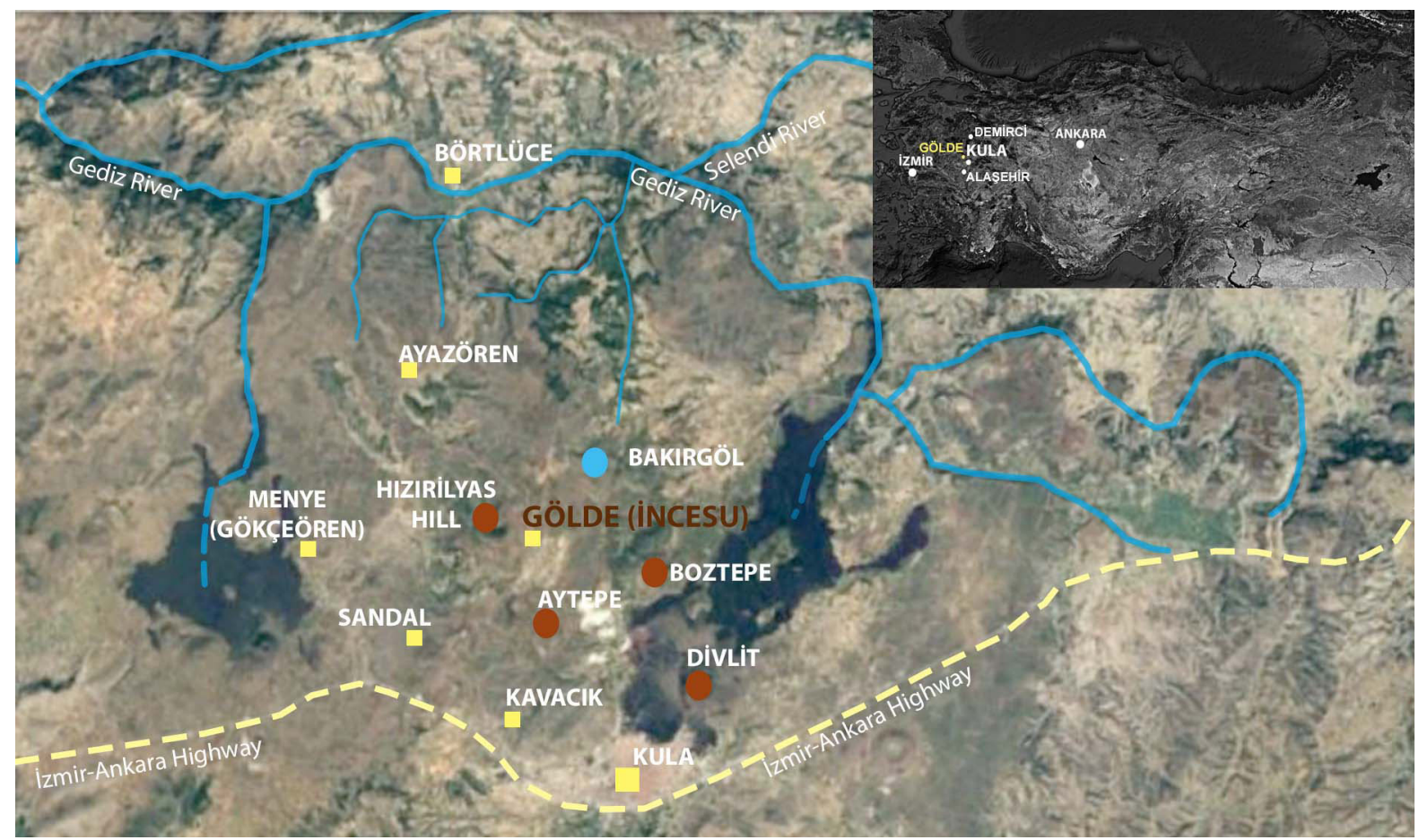

Figure 1. Location of the study area, Gölde (Incesu), with surrounding natural elements and settlements (base map data (C) 2020 Google).

Turkish migrants from the Balkans settled in most of the neighbourhoods abandoned by the Rums. However, Turkish immigrants did not settle in Gölde after the population exchange. Rather, the local Turks continued to live there, resulting in a relatively slow physical transformation, and making Gölde one of the best-preserved rural settlements where traditional life still continues.

This paper aims at a holistic understanding of the traditional rural dwelling characteristics of Gölde. As well as physical features, daily practices, customs, traditions and local values are also considered as factors in the formation of the dwellings. Specifically, this paper seeks to shed light on the following points:

- The main factors that shaped the traditional Gölde dwellings

- The characteristics of these dwellings

- Possible differences between the dwellings of the two ethnic groups (Turks and Rums)

- The effects of changes in culture, economy, and daily life on the dwellings.

With these aims, site surveys were conducted in Gölde over a period of seven days in May and July of 2017. A total of 136 traditional dwelling units were identified, 68 of which are still inhabited. Ten of the houses are in ruins. A further 40 have been totally abandoned, and 18 are currently used only for the storage of household goods and agricultural products (Fig. 2, left). Of the 136 remaining traditional dwellings, 43 were studied in detail, both internally and externally. Sixtyeight houses could only be examined externally because they had locked courtyard doors. The remaining 25 traditional dwelling units could not be analysed, either internally or externally, due to locked courtyard doors and high courtyard walls (Fig. 2, right).

A further analysis of the settlement characteristics revealed that the 136 documented dwelling units were not all in their original state, as some had experienced alterations, lot subdivisions or unifications over time. Site reconstruction analysis revealed 90 dwelling units in their original condition. Thus, all of the information relating to the traditional Gölde dwellings refers to these 90 dwelling units.

Interviews were conducted with local Turkish inhabitants. Although all of the interviewees had secondhand information, the older inhabitants were able to provide information about traditional life in Gölde prior to the population exchange. Rather than conduct structured interviews, conversational dialogues were conducted with 19 Gölde locals. This process allowed for a variety of topics on the history of Gölde to be explored, including traditional daily life-practices and how these practices changed over time, use of space in and around the house and how this changed over time, traditional building materials and methods of construction, information about life before the 1920s, passed down from parents and grandparents, and significant places in the close vicinity of Gölde. The participants comprised 6 females and 13 males, who ranged from 45 to 89 years of age (Table 1). The interviewees 


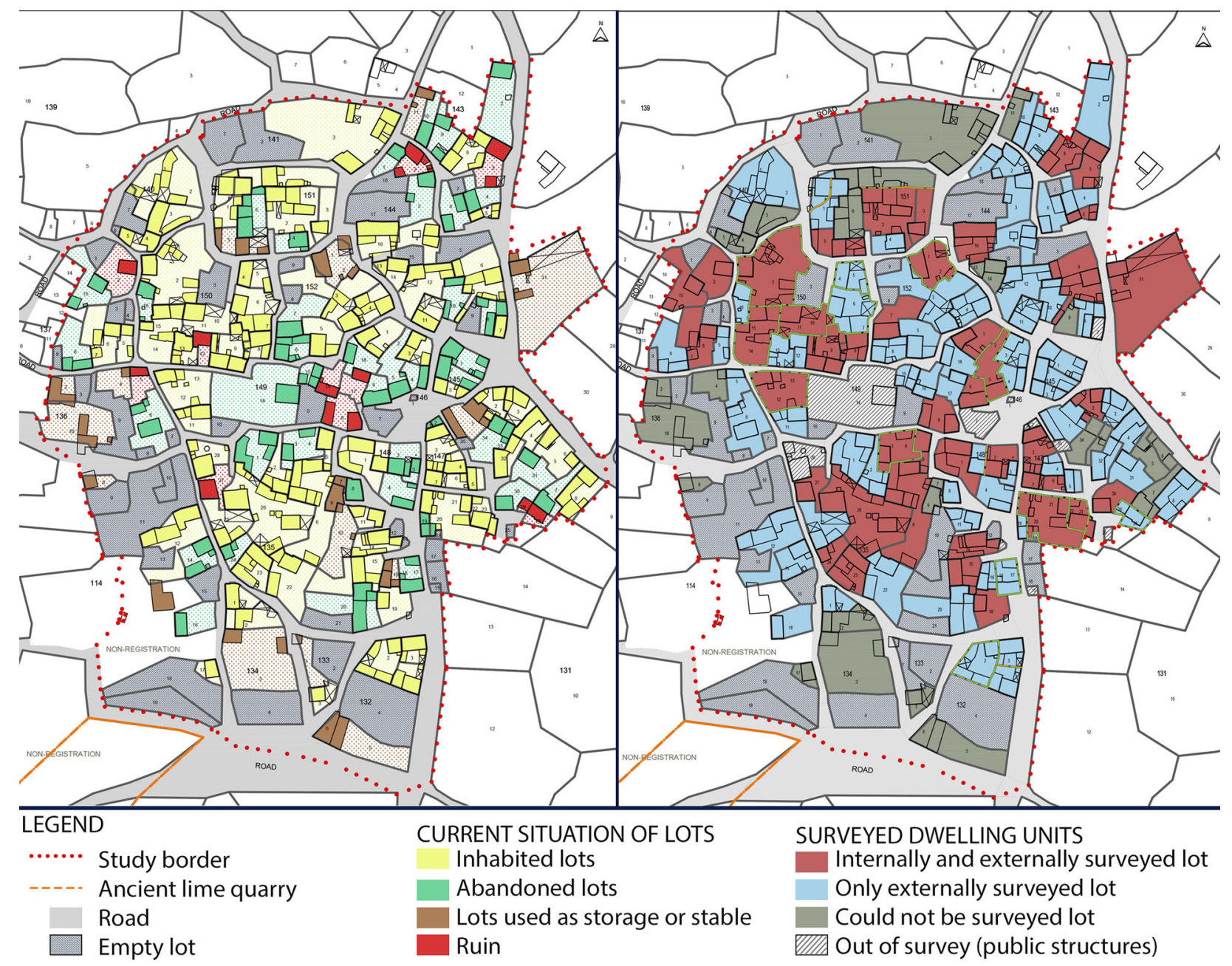

Figure 2. Current condition of the dwelling units (left) and the surveyed dwelling units (right).

Table 1. The local Turk interviewees. All of the interviews were conducted in 2017.

\begin{tabular}{lll}
\hline Initials, gender, date of birth & Place of birth & Profession \\
\hline MC,, male, 1970s & Gölde & Headman (Mukhtar/local authority) \\
IM, male, 1933 & Gölde & Farmer \\
HC, male, 1953 & Gölde & Farmer \\
SC, female, 1959 & Gölde & Farmer \\
DB, female, 1955 & Gölde & Farmer \\
YB, male, 1944 & Gölde & Farmer \\
IB, male, 1932 & Gölde & Farmer \\
ME, female, 1945 & Gölde & Farmer \\
OG, male, 1937 & Gölde & Farmer and stonemason \\
HÇ2, male, 1970s & Gölde & Farmer \\
AG, female, 1940s & Gölde & Farmer \\
YD, male, 1950s & Gölde & Farmer \\
RG, female, 1941 & Gölde & Farmer \\
SU, male, 1952 & Gölde & Farmer and stonemason's apprentice \\
AU, male, 1940s & Gölde & Farmer \\
SG, female, 1936 & Gölde & Farmer \\
HU, male, 1930s & Gölde & Farmer - former headman \\
ŞT, male, 1950s & Gölde & Farmer \\
NA, male, 1950s & Gölde & Farmer \\
\hline
\end{tabular}


Table 2. Rum interviewees, obtained from the CAMS archive.

\begin{tabular}{lll}
\hline & \multicolumn{2}{c}{ Interviewee } \\
\cline { 2 - 3 } Interviewer, interview date & \multicolumn{1}{c}{ Name, gender, date of birth } & Place of birth \\
\hline Ermolaos Andreadis, 1963 & Katina Peazoğlu, female, 1880 & Gölde \\
Ermolaos Andreadis, 1963 & Kharalampos Khatzilambidis, male, 1897 & Gölde \\
\hline
\end{tabular}

comprised mostly farmers, a headman (mukhtar/local authority), a previous headman, a stonemason and an apprentice.

In addition to the narratives of the current locals, oral accounts of two Rum locals from Gölde were provided by the Centre for Asia Minor Studies (CAMS) in Athens, Greece. These interviews were conducted in 1963 and the main aim was to understand life in Gölde prior to the population exchange (Table 2). Although the narratives of these two Rums provided information about various aspects of life in Gölde, such as livelihoods, professions, social and commercial relations with neighbouring settlements, traditions, daily life practices and settlement patterns, they unfortunately contained almost no information relating to the dwellings.

The site survey data were used to understand the physical characteristics of the dwellings in terms of spatial characteristics, architectural elements, construction techniques and materials. Site survey data were also used to decipher alterations to the dwelling units over time. The oral history narratives provided information on social and cultural issues related to the dwelling units. Data obtained from the site survey and oral history studies were then correlated to provide a holistic understanding of the rural dwelling characteristics of Gölde.

\section{GÖLDE AT THE TURN OF THE TWENTIETH CENTURY}

Gölde is situated within a landscape formed by centuries of volcanic activity. The region includes volcanic cones of different sizes as well as numerous morphological features related with volcanism, seismic activity and other geographical features. ${ }^{9}$ The settlement of Gölde is located at the south-eastern outskirts of one of the volcanic cones, which is known as Hızırilyas Hill today (Fig. 3). There exist other volcanic hills in the close vicinity, such as Aytepe and Boztepe, which have been utilised for agricultural and animal husbandry activities (Fig. 4).

Gölde was a typical inner Aegean village at the turn of the twentieth century. Muslim Turks and Orthodox Christian Rums lived side by side. Information gleaned from interviews, along with survey data, revealed that the Turks and Rums lived in different neighbourhoods. However, the two ethnic groups cooperated in a collective economy. The Turks were responsible for agriculture and animal husbandry. Grain, chickpea, sesame, melon, common vetch, bitter vetch and olive oil were the main agricultural products. The agricultural areas where these products were harvested were called kesik by the locals, and these fertile lands extended to the surrounding settlements from the residential core in Gölde (Fig. 4). ${ }^{10}$ The Rums also had lands, but their interest in agriculture was limited to viticulture. The Turks worked on their lands for a fee. Their vineyards were located around $\mathrm{H}_{\mathrm{z}} \mathrm{z}$ rilyas Hill and extended to Sandal village (Fig. 4). Rum interviewee Khatzilambidis stated that:

We mainly dealt with trade. This job was sweet. It gave us bread. Our people travelled through Turkish villages on carriages and sold goods. Mainly small items were sold, such as fabric, thread, needles, thimbles, and matches. Groceries were also sold. They would exchange them for agricultural products, such as wheat, corn, sesame, and hash. These exchanged products were sold in Kula Bazaar by our people. ${ }^{11}$

Other than these itinerant dealers who travelled to neighbouring settlements like Kavacık, Sandal, Menye and Kula to sell their goods, some Rums had shops in Gölde, and some even had shops in nearby Turkish villages, such as Sandal and Demirci (Fig. 1). The owners of these shops lived in those villages, separated from their families. However, Kula was the central marketplace for the locals of Gölde and neighbouring villages. As Khatzilambidis noted: 'Our marketplace was Kula. We already had shops in Gölde where we could buy things that we needed urgently. However, Kula was quite close. It was about a 45 -minute ride. Why wouldn't we shop from Kula?'. ${ }^{2}$

Rums were also involved in crafts and construction. Interviewee YD described Rums as 'artists'. ${ }^{13}$ Rum builders and craftsmen also worked in neighbouring villages. Rum interviewee Peazoğlu stated: 'We had craftsmen in Gölde. My father was a blacksmith. He went to Turkish villages at harvest time to horseshoe their animals. He was paid in wheat instead of money'. ${ }^{14}$

Other than trade and construction works, there were also good social relations between Gölde and other neighbouring villages that hosted Rum communities, such as Menye (Gökçeören), Philadelphia (Alaşehir) and Koula (Kula) (Fig. 1). The Rums of Gölde were religiously connected to the Philadelphia Cathedral and they visited the bishop there to acquire wedding and 


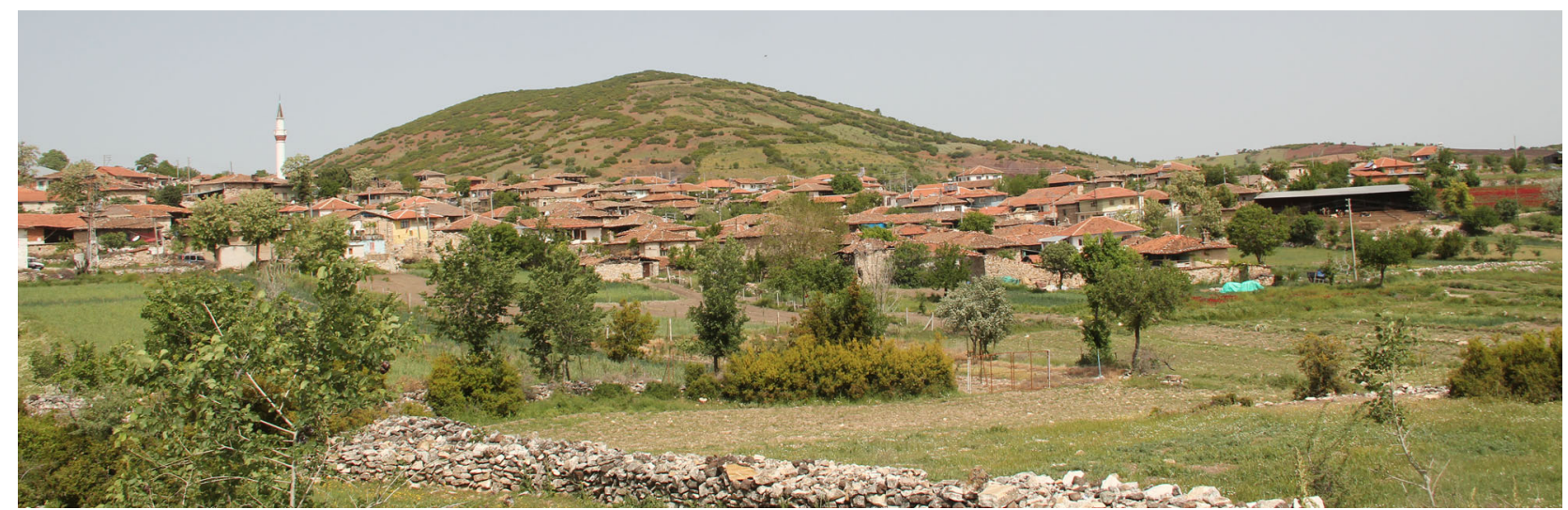

Figure 3. View of the residential area in Gölde (Incesu) at the foot of Hızırilyas Hill.

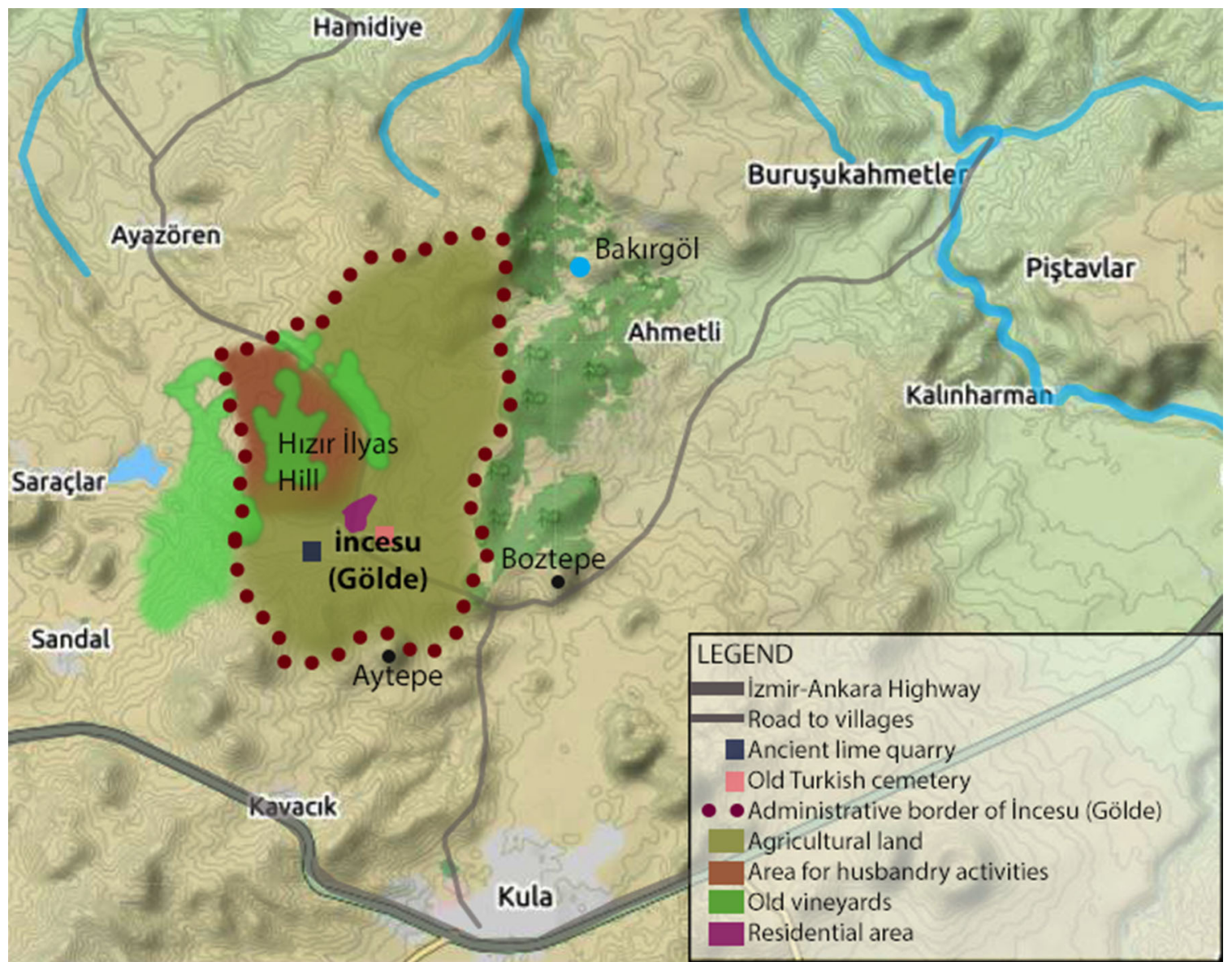

Figure 4. Gölde settlement and its close vicinity (base map data (C) 2020 Google).

baptism documents. However, Gölde was the religious centre for the Teofania Festival, which was celebrated in Hagia Triada Church in Gölde and attracted Rums from neighbouring villages. ${ }^{15}$ A key element of the festival was the opening of the ayazma in the courtyard of the church. The ayazma was similar to a water well and it had a locked metal cover. Closed during the year, it was opened during the festival by the priest from Kula. It was believed that, if the water level was low, evil would come into the settlement. Thus, the Turks were also curious about the level of the water. Peazoğlu revealed that local Turks asked about it curiously: 'What is the level of your ayazma? Is it high or low?'. 16

While no clear neighbourhoods exist in the settlement today, Khatzilambidis emphasised that there were two Rum neighbourhoods known as Taksiarhis and Hagia Triada, in addition to the Turkish neighbourhood. ${ }^{17}$ 


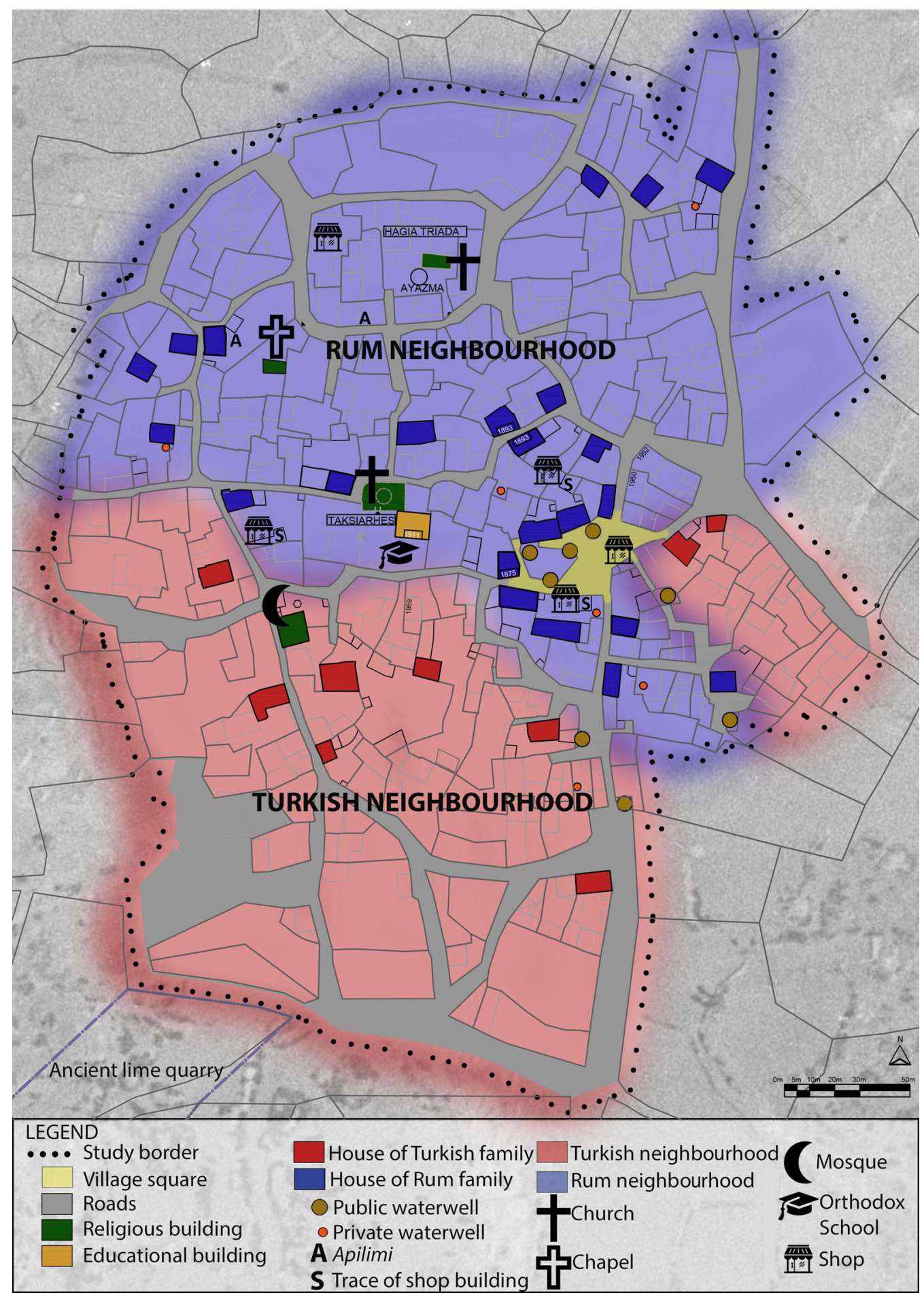

Figure 5. Gölde settlement prior to the population exchange in 1923.

Although the locations of the mosque, Orthodox school and collapsed churches provided information about the positioning of neighbourhoods, it was not possible to distinguish the exact border of two ethnic groups due to the fact that the same materials and construction techniques were used for their houses. However, three houses identified their first owners through Greek inscriptions above the entrance doors. Interviews with local inhabitants also helped to identify the first owners of 37 houses. Using the information obtained from the buildings and from locals, a hypothetical border of the Rum and Turkish neighbourhoods could be determined. Two Rum neighbourhoods were located in the north, whereas the Turkish neighbourhood was located in the southern 


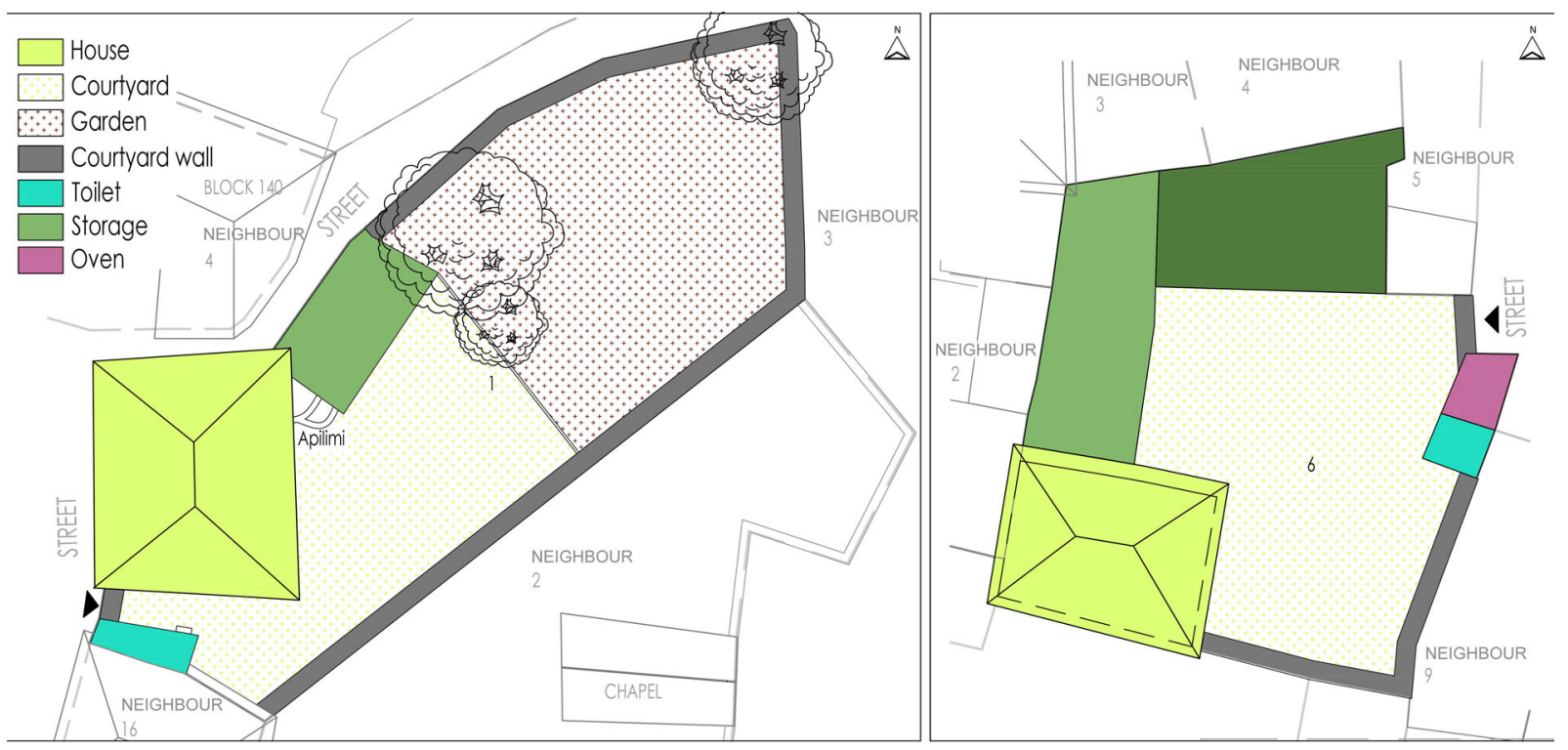

Figure 6. Reconstructed drawings of two dwelling units. DB's dwelling in the Rum neighbourhood (left) and IB's dwelling in the Turkish neighbourhood (right).

part of Gölde. There is also a small plot belonging to Turkish community at the south-east of the Rum neighbourhood (Fig. 5).

The lives of the Rums and Turks in Gölde became turbulent at the beginning of the twentieth century, as was the case with many other settlements that hosted both ethnic groups, and the Rums left Gölde with the defeat of the Greek army in 1922. ${ }^{18}$ In accordance with the resettlement policy followed by the newly established Turkish Republic, the Turks coming from the Balkans were settled in places that the Rums had left. However, no immigrants were settled in Gölde; rather, the ownership of the Rum houses passed to the state. While some of the houses were left to decay, others were sold to existing Turks. ${ }^{19}$

After the migration of the Rums, the Turks maintained their interest in agriculture and animal husbandry. This included sheep and goat farming, in addition to cattle. On the other hand, viticulture disappeared due to fact that the Turks did not have the relevant knowledge. Commercial activities became limited to selling agricultural and animal husbandry products in Kula Bazaar. Traditional construction activities continued down to the 1970s by Turkish builders who had learned from Rum masters. ${ }^{20}$

Interviewee HU emphasised that, during the 1940s, weaving was also a significant source of income for the locals in Gölde. ${ }^{21}$ At this time, some young Gölde locals went to work in the Kula Mensucat Factory, which was established in 1940. When the factory closed in the 1950s, some of the locals established their own carpet looms in the courtyards of their dwellings and individual production continued for a while. However, the majority of people with qualifications migrated to more developed towns and cities. This was not only due to the limited economic opportunities in Gölde, but also the lack of local educational facilities. While the total population of Gölde was around 600 during the 1960 s, according to census data, by 2020 , there were only 172 residents. The majority of this population was over the age of $50 .^{22}$

\section{DWELLING UNITS}

Traditional dwelling units in Gölde were situated on large lots due to the need for privacy and the requirements of the agricultural economy. Each lot was surrounded by high stone masonry walls to prevent direct vision from the street. In addition to the two- or threestoreyed residential houses, several other service spaces were located within the lots, such as storage for agricultural products, stables, hay barns, poultry houses, toilets and ovens. The open spaces within the lot formed the courtyard. In some dwellings, a garden was also present (Fig. 6).

\section{THE COURTYARD AND ITS ELEMENTS}

The courtyard was a semi-private, open space. It was not only the gathering place of the family members and neighbours, but also where the production activities and daily functions of the household took place. ${ }^{23}$

The courtyard was as large as required by the agricultural-based rural lifestyle. It was the place where food was prepared and cooking, vegetable drying and other household activities took place. Harvest products were also processed and stored in the courtyards. 


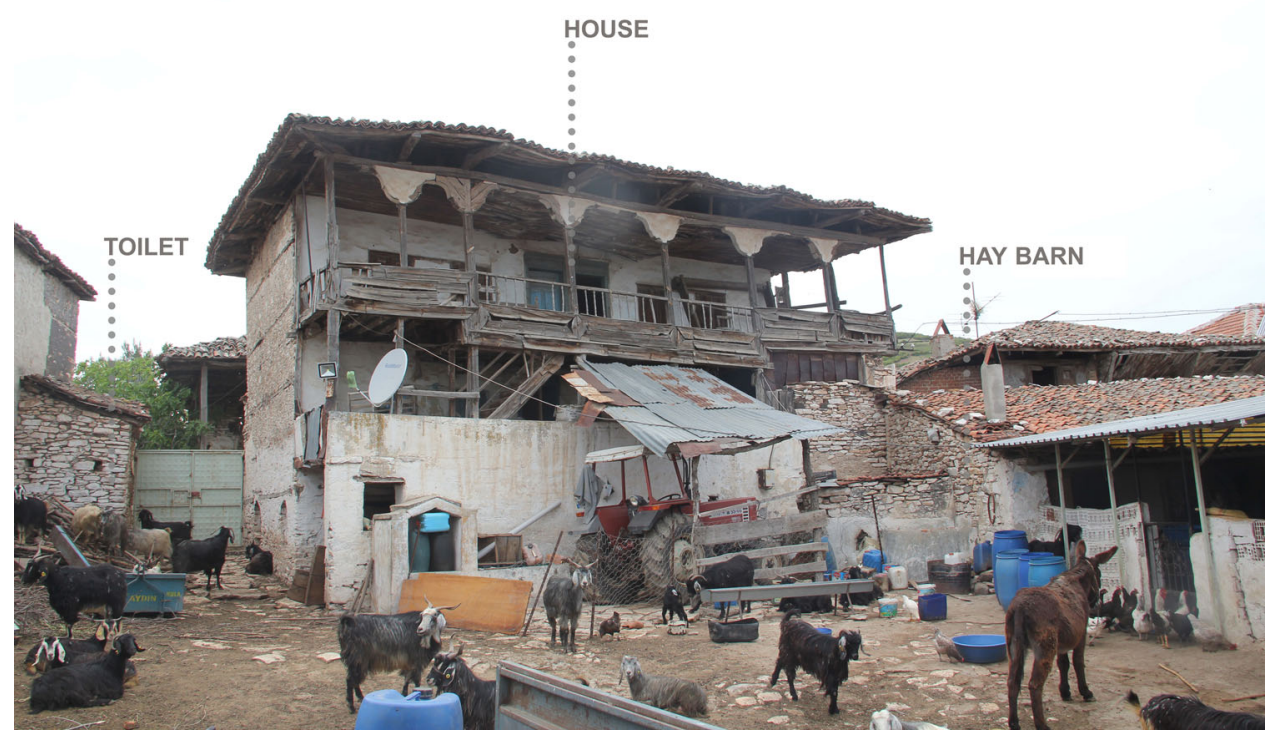

Figure 7. DB's dwelling unit. The unit comprises the house, various service buildings and the courtyard. The stable, hay barn, toilet, poultry houses and storage spaces in the courtyard are visible. The courtyard serves as an open shelter for the sheep and chickens during the daytime.

Today, agricultural vehicles such as tractors and patoz (threshing machines) are also kept in the courtyards. These vehicles are housed under cover to protect them from the rain. Except when grazing, and at night, the sheep and poultry were free to roam in the courtyard during the day (Fig. 7).

Gardens were used to grow flowers and vegetables. While courtyards were covered with slate stone, the gardens were of soft earth. Three dwelling units with gardens were identified, all of them in the Rum neighbourhood. Former Gölde native Peazoğlu recalled in 1963: 'We had courtyards with gardens. We also had fruit trees like mulberry, quince, and pomegranate. There were ten mulberry trees in our garden'. ${ }^{24}$

Other than the house, hay barns were a common element of the courtyards. These were single-storey stone buildings that were generally attached to the house and were used for the storage of straw (Fig. 7). As a result of a growth in small cattle farming, new stone stables were added to the courtyards of some houses over time.

The toilets were generally attached to the street-facing wall of the courtyard (Fig. 7). Locals stated that this location was chosen so that sewage could be drained from the street at specific time intervals. ${ }^{25}$

In traditional dwelling units, the kitchen was generally a separate service building in the courtyard. However, only one kitchen building can be observed in Gölde today (Fig. 8, left). It is found in the courtyard of RG's house which is described by the current landlords as a Rum house. The landlords believe this to be the original kitchen. ${ }^{26}$ The fact that the building was built with local materials and techniques strengthens this argument.

Ovens were also commonly observed in the courtyards (Fig. 8, right). Though ovens can be found in many of the lots at present, interviewee DB stated that, in the past, not every family had their own oven. Instead, they used the ovens of their neighbours to make bread. ${ }^{27}$ Additionally, according to interviewee $\mathrm{OG}$, the construction of the original ovens was different from that of the current rectangular ovens. Since no original ovens were found during the fieldwork, OG explained the technique used to construct them:

Ovens were only built by first generation stonemasons. We cannot construct them. Firstly, a rectangular stone platform was constructed. Then, a semi-circular wooden framework was made, and flagstones were aligned vertically around the framework by placing them like upside-down steps that hung $1.5 \mathrm{~cm}-2 \mathrm{~cm}$ above the ground on the inside, forming an arch. In the final step, the keystone was placed between two stones at the top of the oven. ${ }^{28}$

Other distinctive elements in the courtyard were identified in some houses. These included a number of private water wells (Fig. 9). These wells were slightly elevated from the ground and covered with a metal cover or a stone (Fig. 10, left). Although Rum interviewees emphasised that the Turkish name for these wells was sarnıç, the current locals called the wells mahzen and they believed that the main function of the mahzen was the storing of wine for fermentation. Thus, the current locals attributed the existence of a 

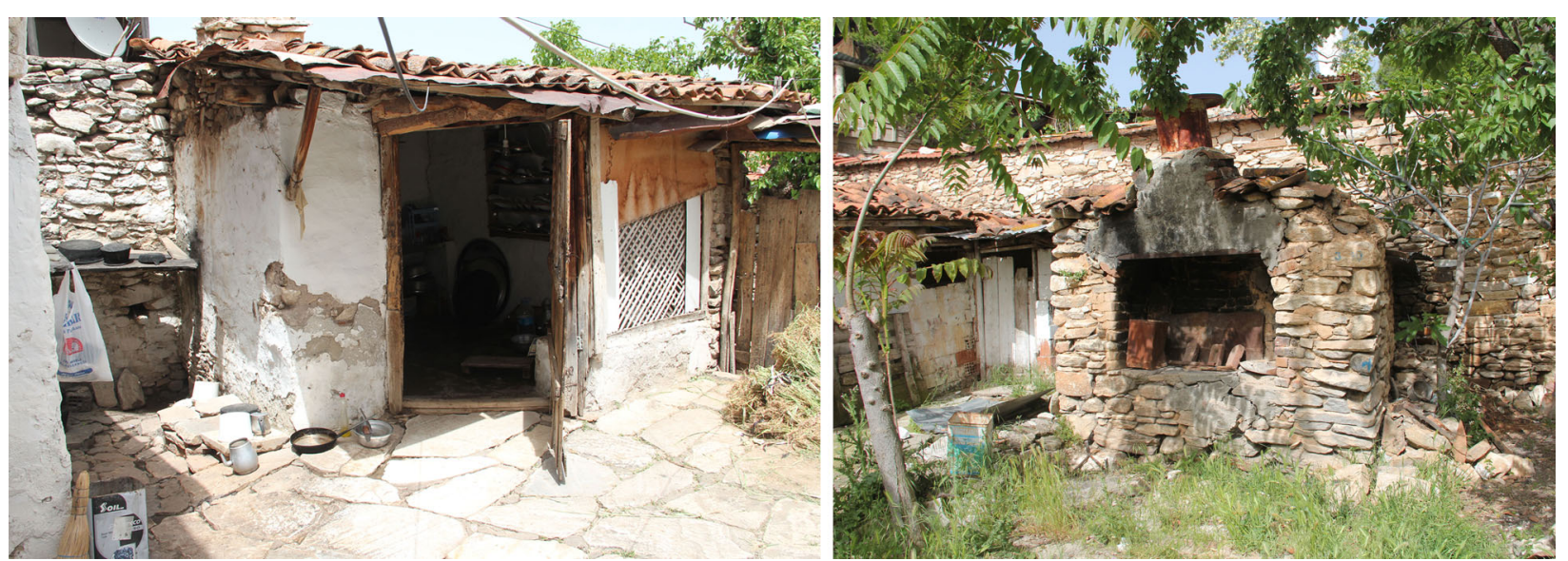

Figure 8. Kitchen in the courtyard of the RG's family (left) and an oven in a dwelling unit (right).

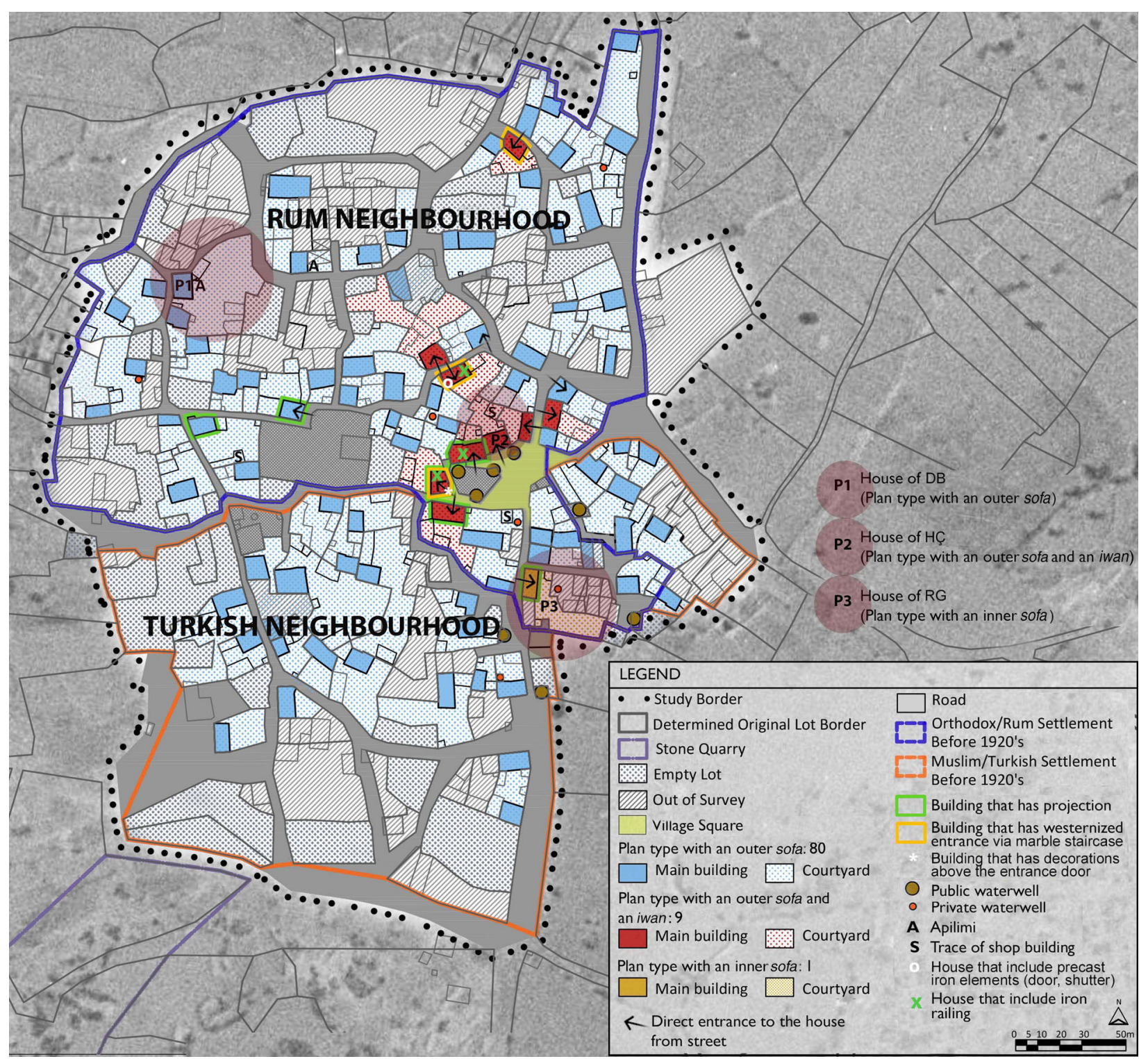

Figure 9. Distribution of houses with distinctive elements and plan types between the two neighbourhoods (P1, P2 and P3 were used as examples of each plan type). 

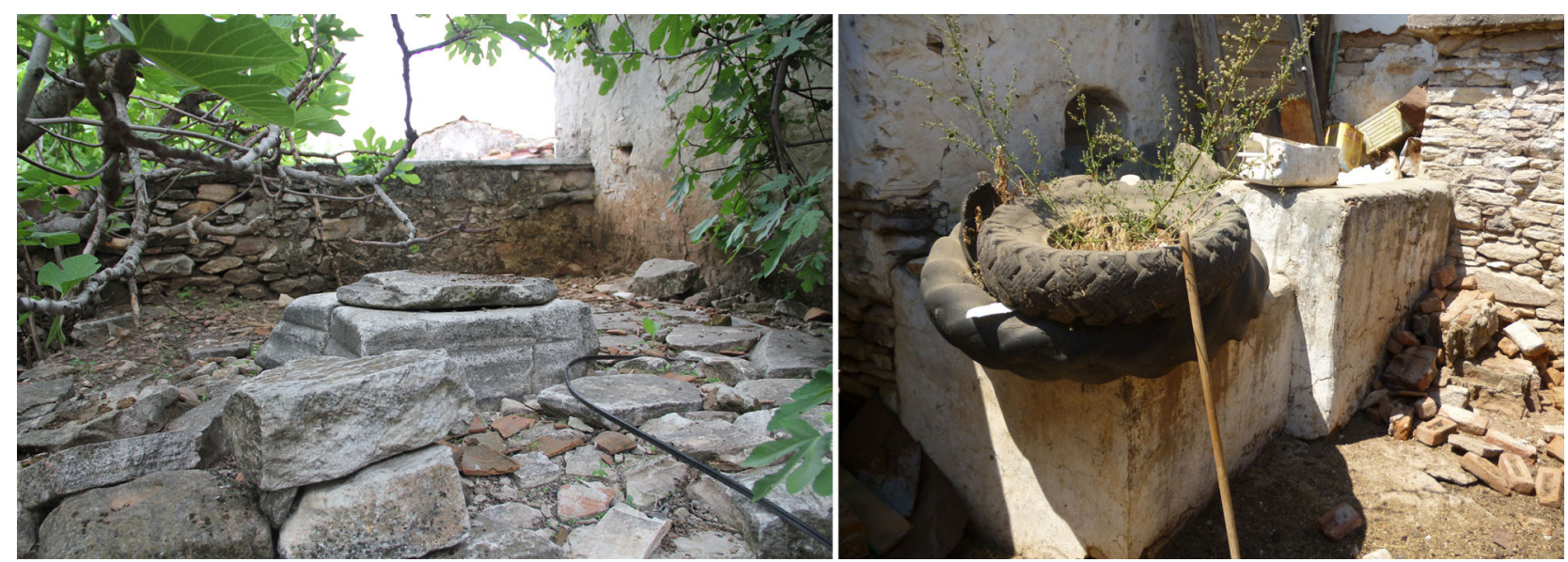

Figure 10. A well to store rainwater in the courtyard of a house (left) and an apilimi attached to the courtyard wall of another house (right).
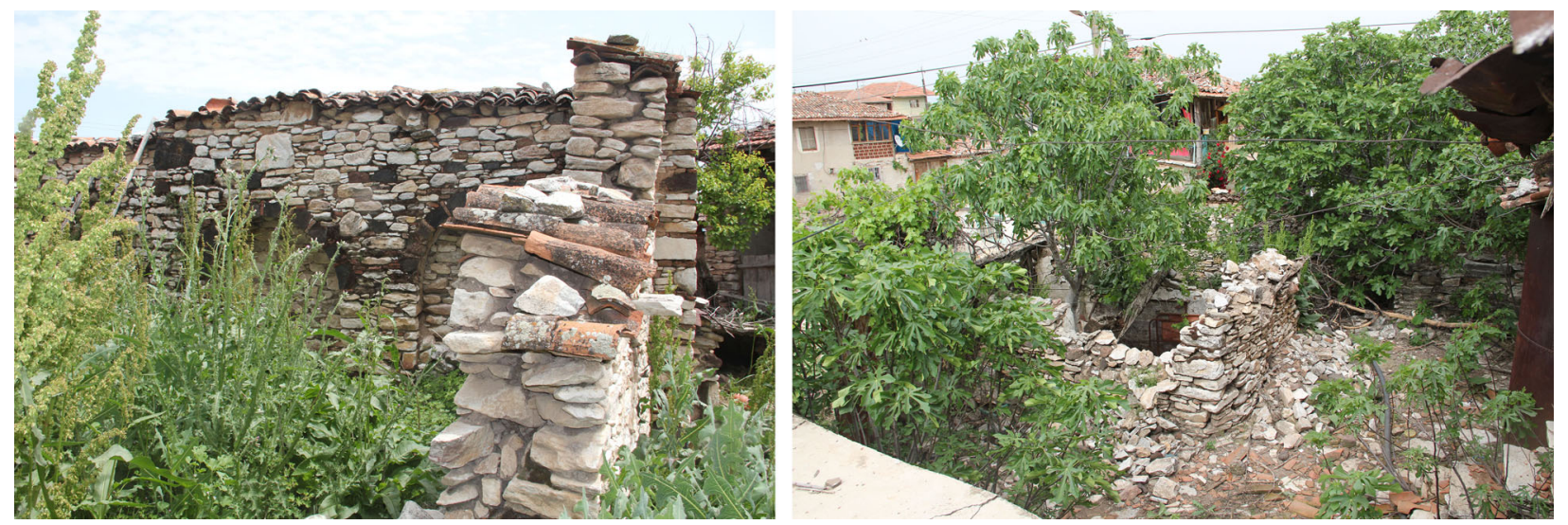

Figure 11. Ruined walls in two dwelling units located within the Rum neighbourhood.
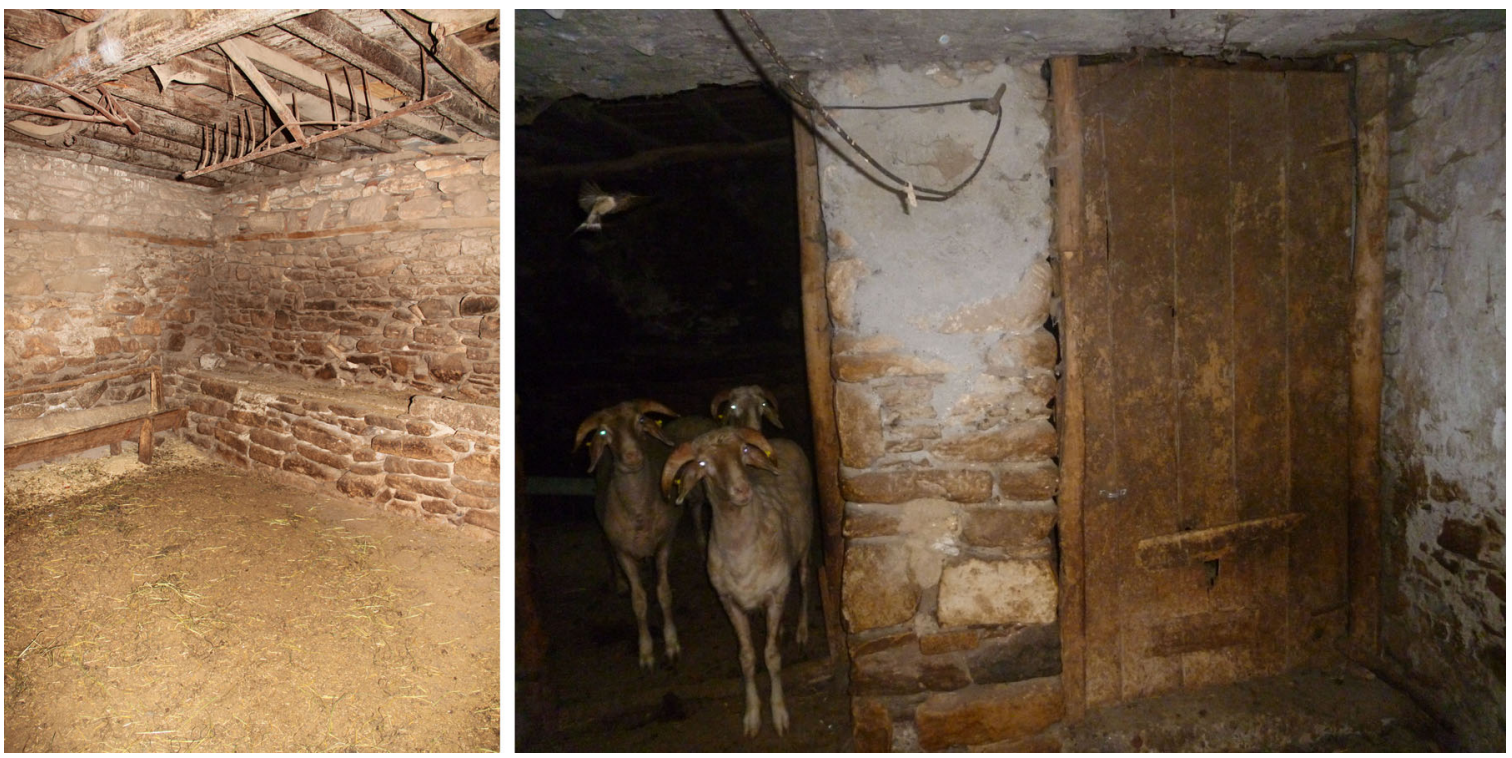

Figure 12. Stable of a house and the low stone masonry platform (tabla), on one side of the stable. 

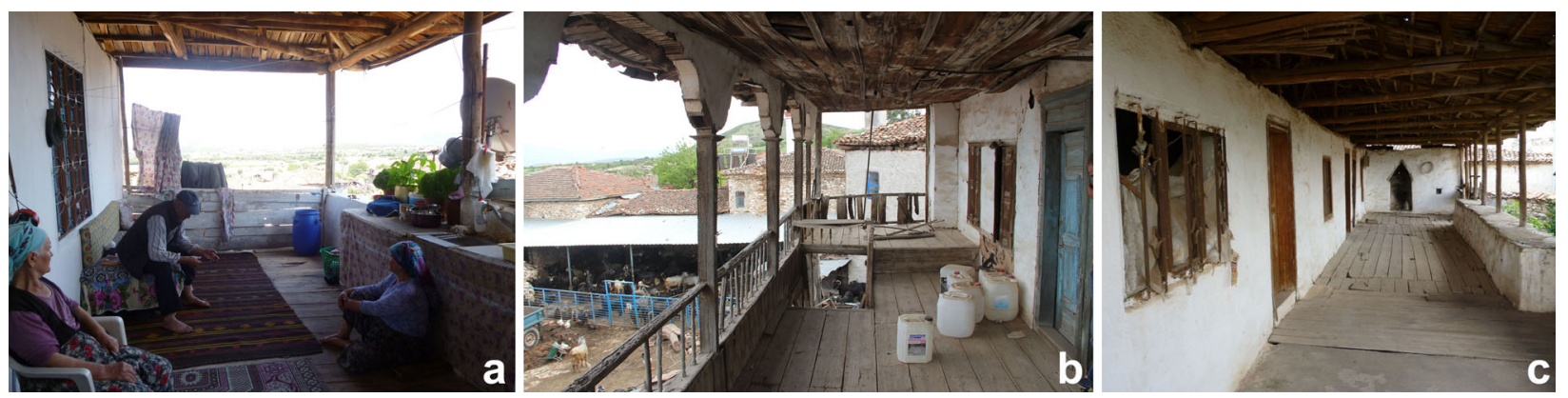

Figure 13. (a) a sofa used for a family gathering, (b) a sofa including seki (raised platform) and (c) the sofa of an abandoned house including fireplace.

mahzen to the first owners of the house being Rum. On the other hand, Khatzilambidis, a Rum native of Gölde, explained:

There were no fountains in Gölde, we drank water from the wells in the square and on the roads. However, some houses had wells that collected rainwater. They were embedded and covered in the courtyards of the houses. Their walls had been robbed. We would take the water out of the bucket, and it was used for cleaning and cooking. ${ }^{29}$

Also associated with the Rum community were two interconnected stone pools that were attached to the inner courtyard walls (Fig. 9, indicated as A). This element was called an apilimi (Fig. 10, right) and it was used to obtain grape juice. After crushing the grapes within the first pool, the grape juice flowed into the other pool from the hole in the base of the first. Only two examples were found during our survey (Fig. 9).

The last distinctive structures were the ruined walls within the courtyards of some of the houses that included specific architectural elements, such as niches or earthen pipes within the walls (Fig. 11). Current locals, EC, IM, HU and İ, emphasised that, while some Rum families had commercial lands in the north part of the settlement, others used the ground floor of their houses, or a building within their courtyard, for commercial activities. ${ }^{30}$ Thus, these ruined walls may have belonged to former shop buildings. The fact that such walls are only seen in the houses located in the Rum neighbourhood strengthens this argument (Fig. 9, indicated as S).

\section{THE HOUSE}

Gölde houses generally had two floors. There were some three-storeyed houses, but these were rare. Typically, the upper floors of the houses were used as the living quarters. Thus, in three-storeyed houses, there were two living quarters.

The ground floors generally had two rooms located at one side of the semi-open entrance space, which was called sofa alt $1 .{ }^{31}$ Both rooms were entered from this space through modest single-leaf wooden doors.
The sofa alt 1 provided circulation between the groundfloor rooms and it was also a place where the agricultural products could be protected from the weather. The ground-floor rooms were mainly used as a stable and hay barn. The stables had a low stone platform called a tabla on one side of the room, which was used to feed the animals (Fig. 12).

In two-storeyed houses, the only vertical access was provided by a stone staircase located outside attached to the courtyard facade of the house. However, in threestoreyed houses, after climbing the stone staircase, access between the two living quarters was provided by a wooden staircase that was located in the semi-open sofa, which was situated above the sofa alt 1 . The sofa was surrounded by wooden posts that supported the roof and upper floor (Fig. 13).

In addition to providing access, the sofa was also the place where agricultural activities were performed and where the family members came together (Fig. 13, a). The seki, at one end of the sofa, was a raised platform (around $30 \mathrm{~cm}$ high) which was used as a sitting area (Fig. 13, b). In some sofas, a fireplace for cooking was also located on one of the walls (Fig. 13, c).

Most houses included a semi-open outer sofa which was open to the courtyard on one side, with the rooms positioned at the other side (Figs 13 and 14). In the Gölde settlement, 80 of 90 houses studied were designed with an outer sofa and they were distributed evenly throughout the settlement (Fig. 9). This typical plan form is generally called a 'Turkish House'. ${ }^{32}$ However, the uniform distribution of this plan type in Gölde, housing both Turk and Rum inhabitants, shows that there is no obvious difference in the way in which living space was used between these two ethnic groups. ${ }^{33}$

In 77 of the 80 houses that had a plan type with an outer $s o f a$, the facade with the sofa was the main elevation facing the courtyard (Fig. 14). The house was entered through the courtyard, which served as a privacy barrier between the house and the street. Only three of the houses that included an outer sofa had the main facade facing the street, with an entrance to the house that was directly from the street. In these three houses, the entrance door opened into an area called 


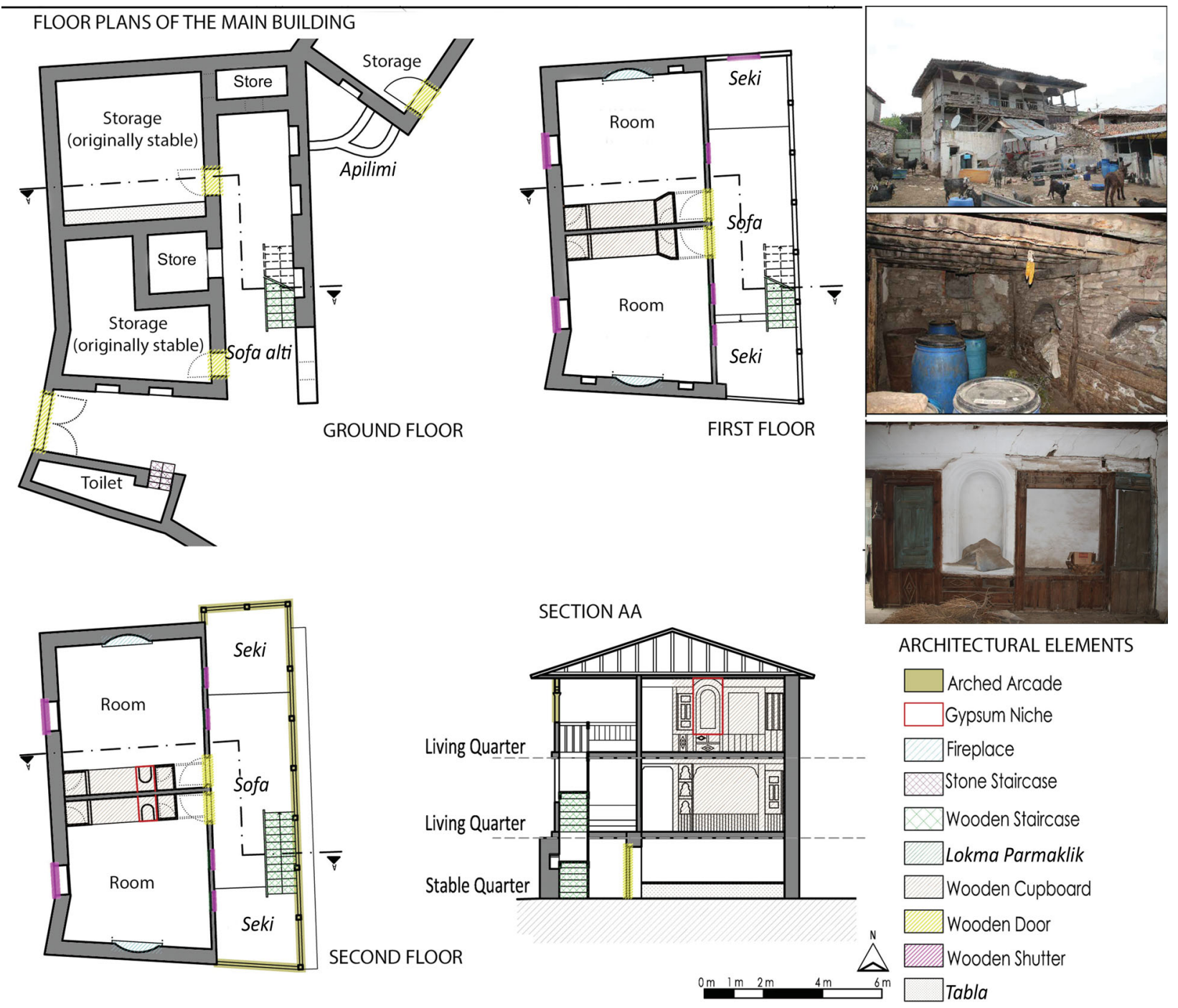

Figure 14. Reconstructed drawing of DB's house, which had a plan type that included an outer sofa (indicated as P1 in Fig. 9).

taşl $l k$ on the ground floor of the house which provided access to the courtyard and upper floors. ${ }^{34}$ While all three houses were located in the Rum neighbourhood, one of them was differentiated from the others because its main facade had projections towards the street on both floors (Fig. 15). In this way, the living space was enlarged, and a direct view of the street was provided with the windows located at the projection (Fig. 15).

Of the 90 houses studied, the plans of 10 houses differ from the typical outer sofa type. Nine of these 10 houses have a plan type that included the combination of a sofa with a semi-open space called iwan, which created a corridor between the two rooms on the first floor (Fig. 16). In this type of plan, while the sofa faced the courtyard, the iwan faced the street and the rooms opened into the iwan. The iwan also included a wooden platform, nearly $60 \mathrm{~cm}$ high, called a sedir, which was used as a sitting area. In this plan type, the facade that included the iwan was the main elevation facing the street. The entrance was from this main facade to the $t a s ̧ l ı k$, which was located below the $i$ wan (Fig. 16).

Among the houses that had this plan type, three reflect some western influences. They had westernised entrances that included marble staircases starting at the street level (Figs 9, 17 and 18). Two were located around the village square and had Greek inscription panels that indicated construction dates as 1875 and 1893 (Fig. 17). One of them, Gölde Evi (Gölde House) that was constructed in 1875 , also had hand-drawn ornamentation above the entrance door (Fig. 17, a). ME's house, constructed in 1893, had a precast iron entrance door in addition to a marble staircase (Fig. 17, b). Another house was located in the northern part of the settlement that had an arched entrance above street level (Fig. 18). Although there is no staircase at present, traces of this could be observed. All three of these houses were located in the Rum neighbourhood (Fig. 9). 


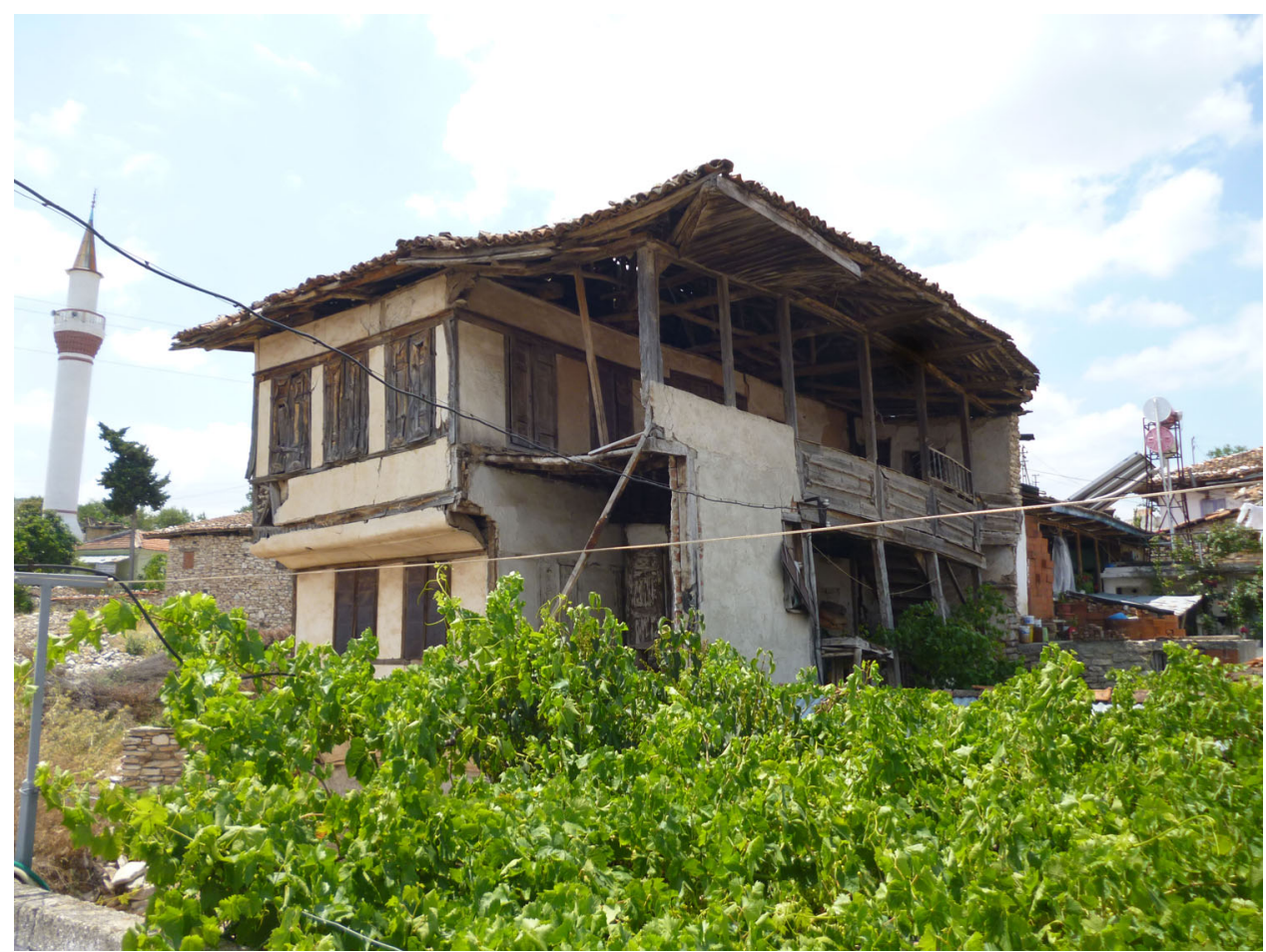

Figure 15. The house that has projection towards the street.

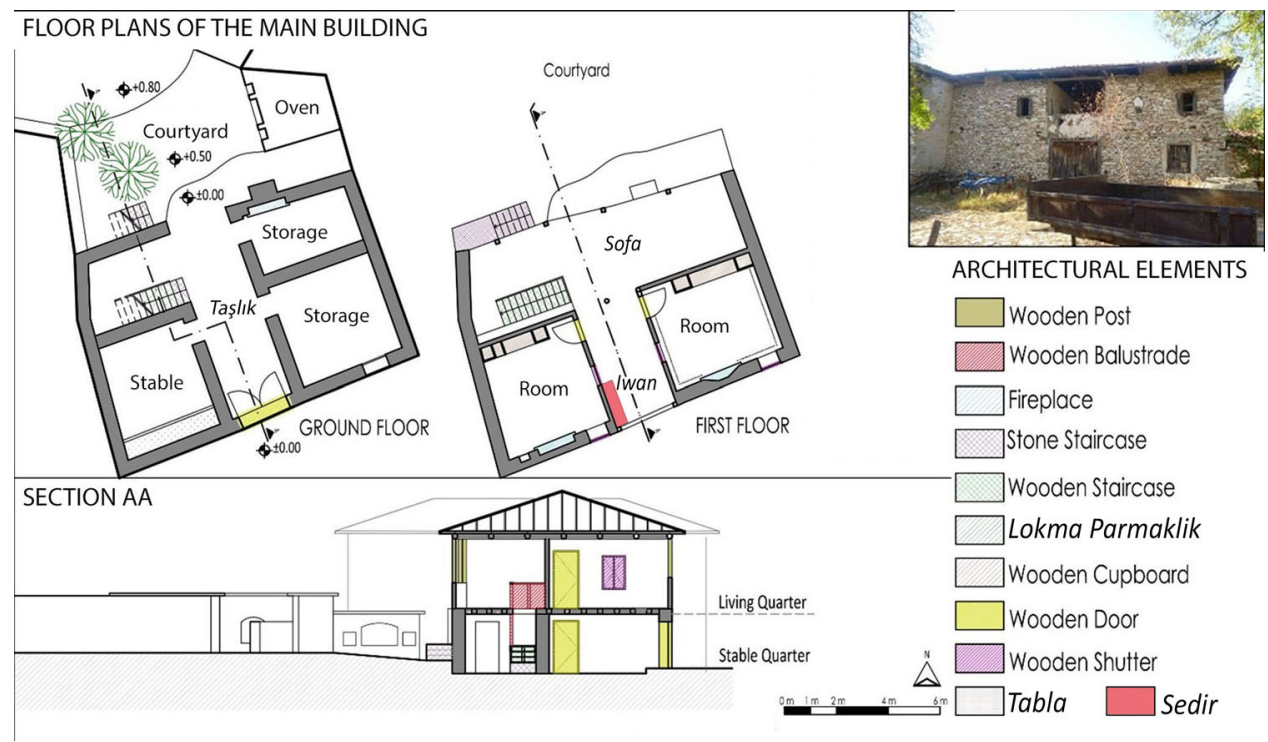

Figure 16. Reconstructed drawing of HÇ's house, which had a plan type that included an outer sofa and an iwan (P2 in Fig. 9).

In addition to these plan types, there was an example of a dwelling, RG's house, that had a plan with an inner sofa (Fig. 19). In this plan type, the inner sofa was located above the taşlı $k$ and was situated between the two first-floor rooms, which were entered from it. The main entrance to the house was from the street through the taşlı $k$ space on the ground floor.

It is worth noting that all ten houses that possess different characteristics than the typical outer sofa type are located in the Rum neighbourhood. The Rum owners of these houses had sufficient capital and vision to express their social and economic difference via their houses. These were probably the trading elites of the Rum community who had strong social and commercial relations with Kula where various westernstyle houses appeared after the mid-nineteenth century. ${ }^{35}$

In all of the houses studied, entrance to the rooms from the sofa was provided by single-leaf wooden doors. These were mostly ornamented with floral and 

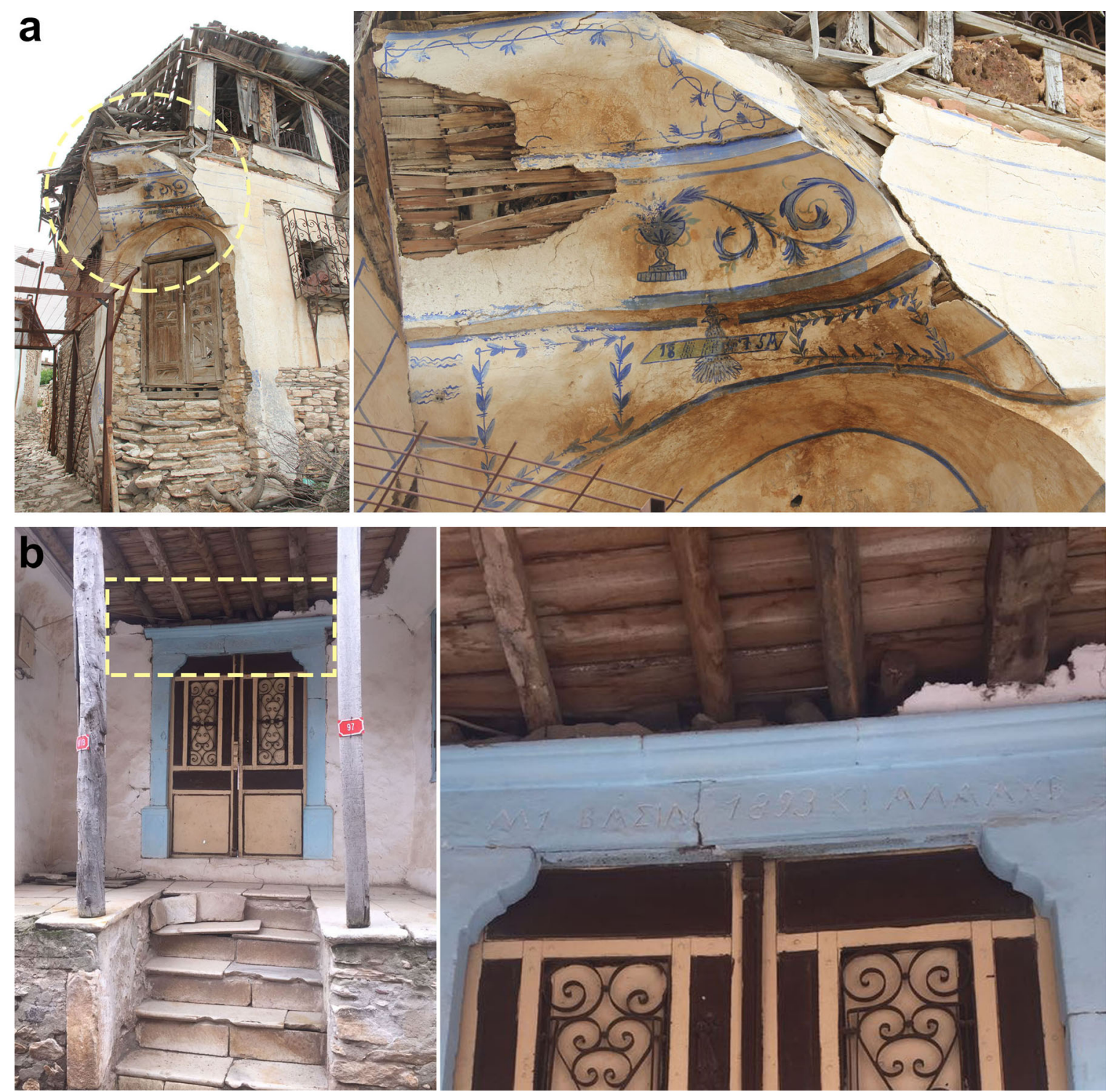

Figure 17. (a) Gölde Evi, located in the village square, with the inscription and hand-drawn ornamentation above the entrance door, and (b) ME's house, which has an entrance from the street directly through a marble staircase and precast iron door.

geometric figures. Sunlight entered the house through the sofa and through window openings. The window openings of the houses of Anatolian towns only consisted of wooden frames and shutters until the nineteenth century. ${ }^{36}$ This can still be seen, especially in the abandoned houses (Figs 15 and 20, b and d).

Other sub-elements of the windows were lokma parmaklı $k$ (barred grills), balustrades and iron railings (Fig. 20). ${ }^{37}$ Lokma parmaklı $k$ and wooden balustrades were found in the majority of houses that were observed internally in both neighbourhoods (Fig. 20, a, $\mathrm{b}$ and $\mathrm{d}$ ). However, iron railings on the windows or iwan were observed only in three houses, all of which are located in Rum neighbourhood (Fig. 9). Çil claimed that these iron railings on the buildings were a later addition, which were added with the purpose of protection from attacks during the tense period between the Turks and Rums. ${ }^{38}$ The fact that these railings are located in the window and iwan openings on the street facades of the three houses located in Rum neighbourhood supports this view.

All of the rooms on the upper floors had similar characteristics and were used in similar ways. Interviewee ST described life in each room:

There are two rooms in this floor [third floor] and two rooms on the floor below. Everyone shared them accordingly. There was no sofa bed like now. There were floor mattresses. We used to get warmer with fireplaces. They used to say, 'one fireplace for three people'. Like braziers now, we used to put fire on the fractures of earthen pots. This was in the middle of the room and rest of the people used to get warmer with it. ${ }^{39}$

As ST explains, the architectural elements of the rooms were organised according to the needs and daily 


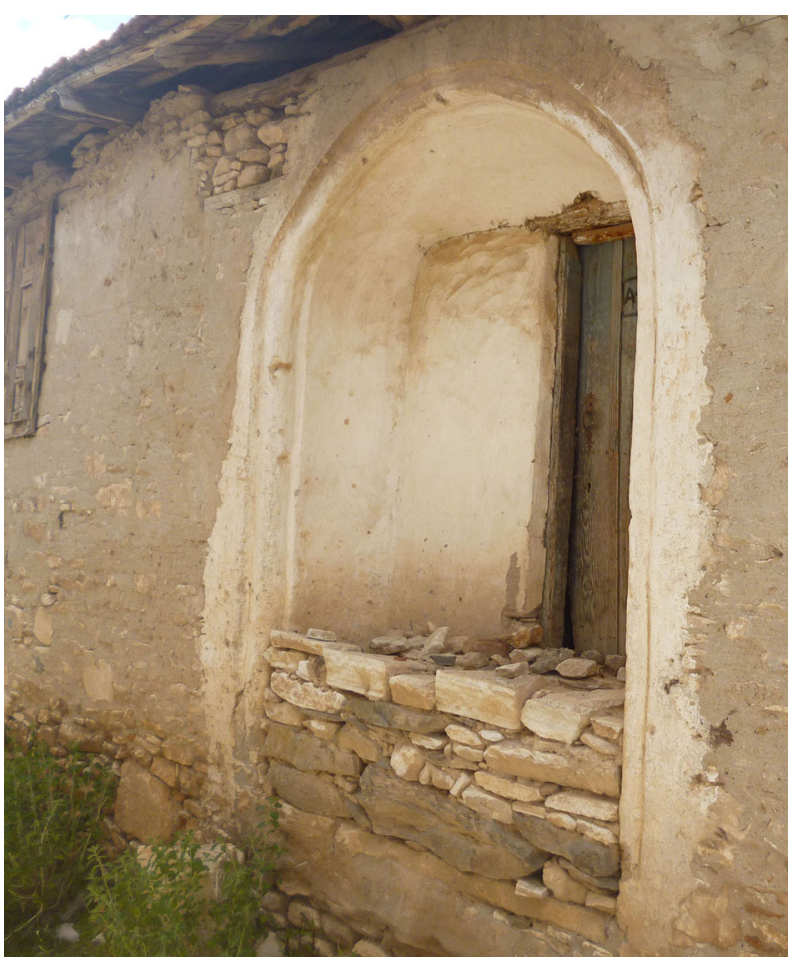

Figure 18. A house that had an arch-shaped entrance on the street facade. activities of the families. ${ }^{40}$ Each room on the first floor of the house was assigned for the nuclear family of a married son of the houseowner. Therefore, as many families could live in a house as there were rooms on the upper floor(s). The rooms were used as living rooms during the day and comprised timber seating elements (sedir) which were elevated nearly $60 \mathrm{~cm}$ from the floor. These rooms were transformed into bedrooms at night by laying down mattresses which were stored in the cupboards (Fig. 21).

The fireplace was located in the exterior wall and provided warmth and cooking facilities (Fig. 21, left). An embedded wooden cupboard could be located on each side of the fireplace, and wooden cupboards might also be found in the partition wall between the rooms. Additional spaces for flowers (çiçeklik) and for bathing (gusülhane) might also be found along this wall (Fig. 21, right). Warm water was transported to the gusülhane using water cans and dirty water was drained to the street through a hole on the floor of this space. A gusülhane was observed in the majority of those houses examined, in both neighbourhoods.

Although the rooms generally had similar characteristics, rooms that were allocated for guests, called başoda, often had more ornamented architectural elements. In particular, some rooms had a ceiling decoration called tavan
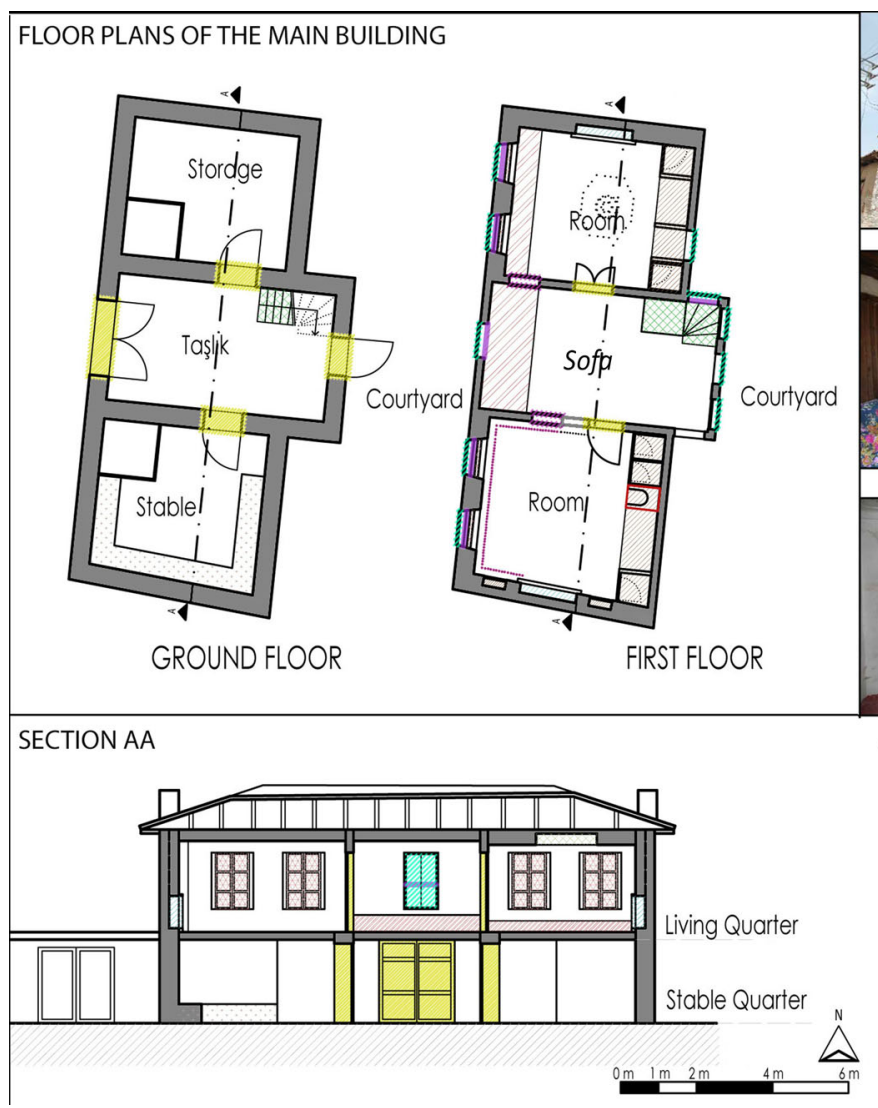
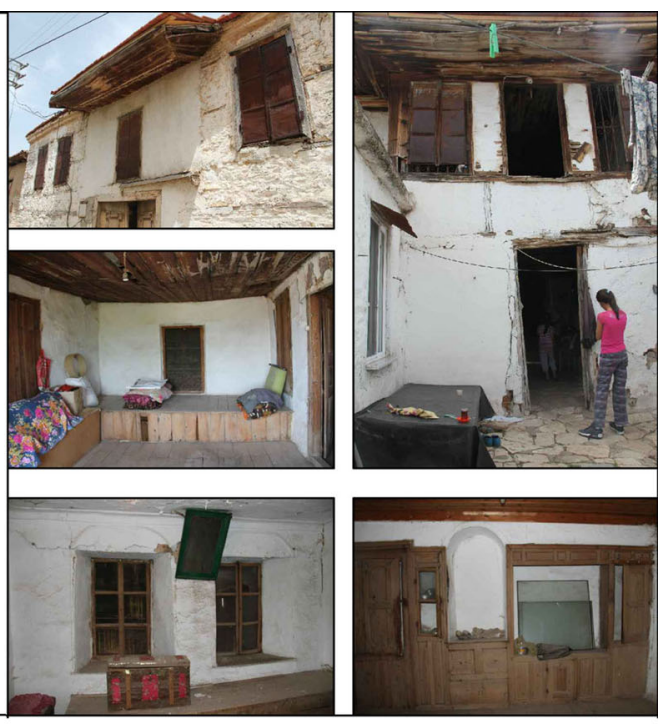

ARCHITECTURAL ELEMENTS

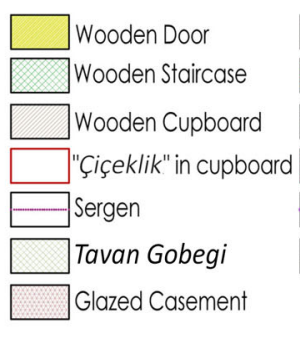

Figure 19. Reconstructed drawing of the RG's house, which had a plan type that included an inner sofa (P3 in Fig. 9). 

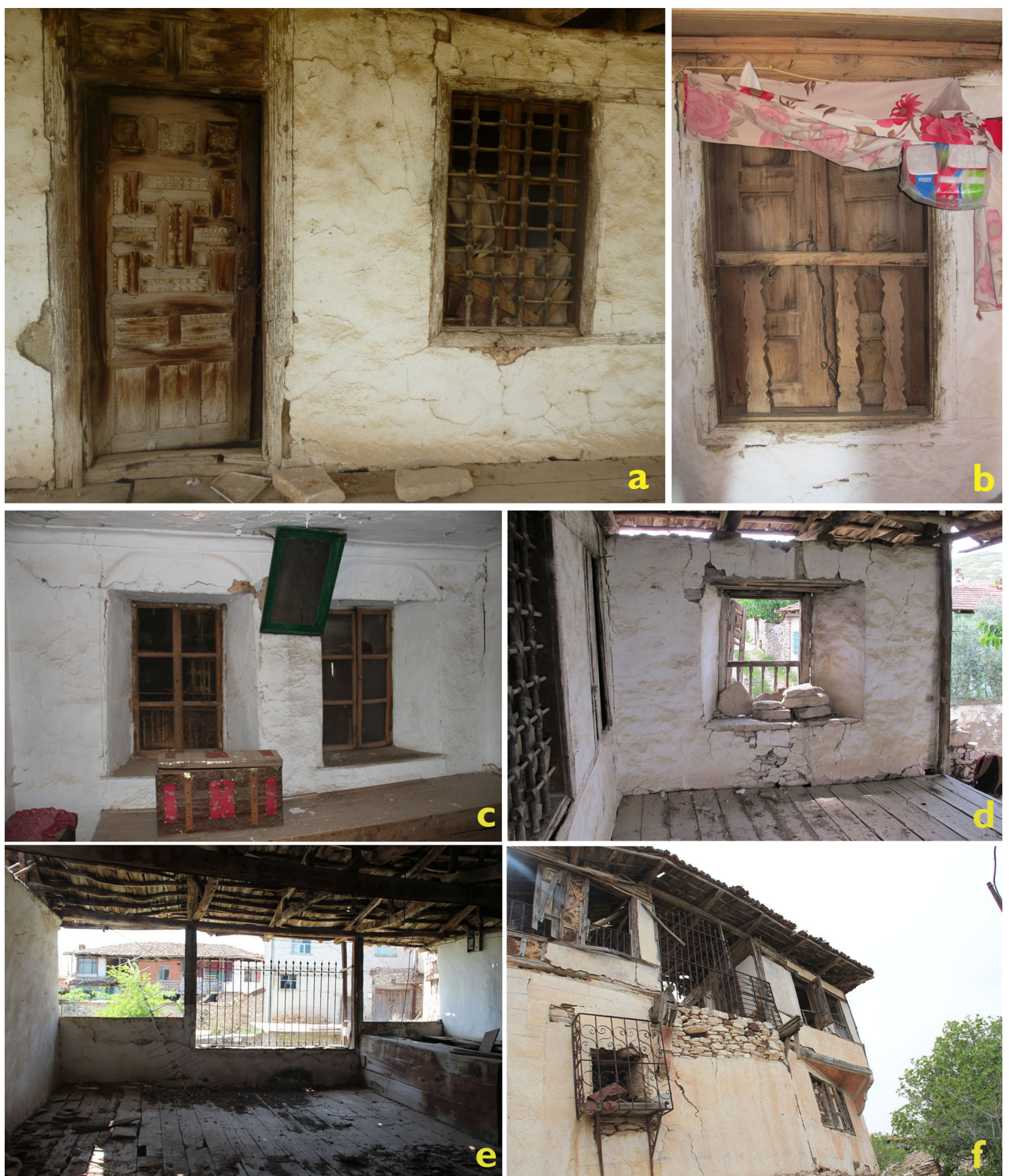

Figure 20. (a) Single-leaf wooden door and lokma parmaklık in the window opening, (b) wooden shutter and balustrade in the window of a room, (c) double-glazed casement windows in a room of RG's house, (d) wooden shutter and balustrade in a sofa window, (e) iron railing in iwan of HÇ's house, (f) iron railing in iwan and window in Gölde Evi.

göbeği. This ornamental feature was located at the centre of the ceiling and was either octagonal or rectangular (Fig. 22). Some scholars suggest that tavan göbeği reflects an old Turkish (shamanic) belief. ${ }^{41}$ According to this belief, tavan göbeg $i$ is located in the centre of the sacred space, which is the projection of the universe on earth, and is an echo of earlier traditions in which the smoke outlet in a dwelling was directly facing the pole star. ${ }^{42}$ However, Asatekin claims that tavan göbeği only reflects the higher status of the room, as well as the economic status of the family. ${ }^{43}$ Among the 43 houses observed internally, tavan göbeği were present in seven houses and only one of these houses was located in a Turkish neighbourhood. The fact that this element is found largely in the Rum neighbourhood suggests that the tavan göbe $\breve{g} i$ was built as an indicator of economic status rather than any spiritual meaning in old Turkish belief.

Although most ceilings were constructed of wooden planks, a ceiling with lime plaster whitewash was 

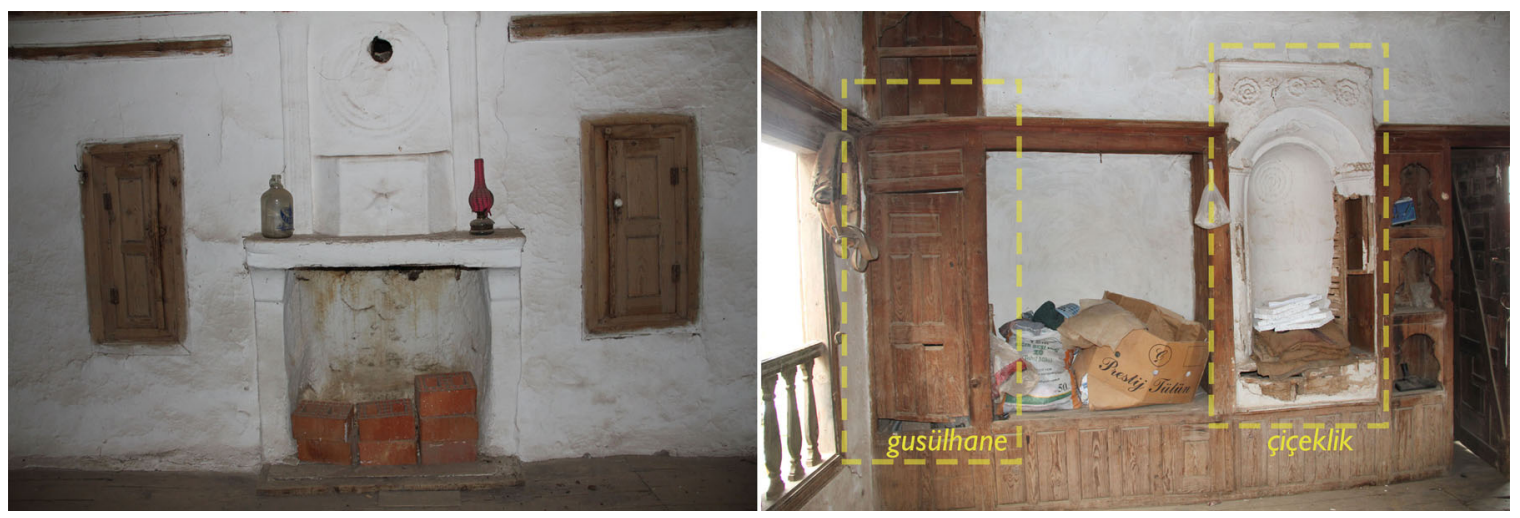

Figure 21. Fireplace with two embedded cupboards (left); gusülhane and çiçeklik in wooden cupboard in the room of a house located in the Rum neighbourhood (right).
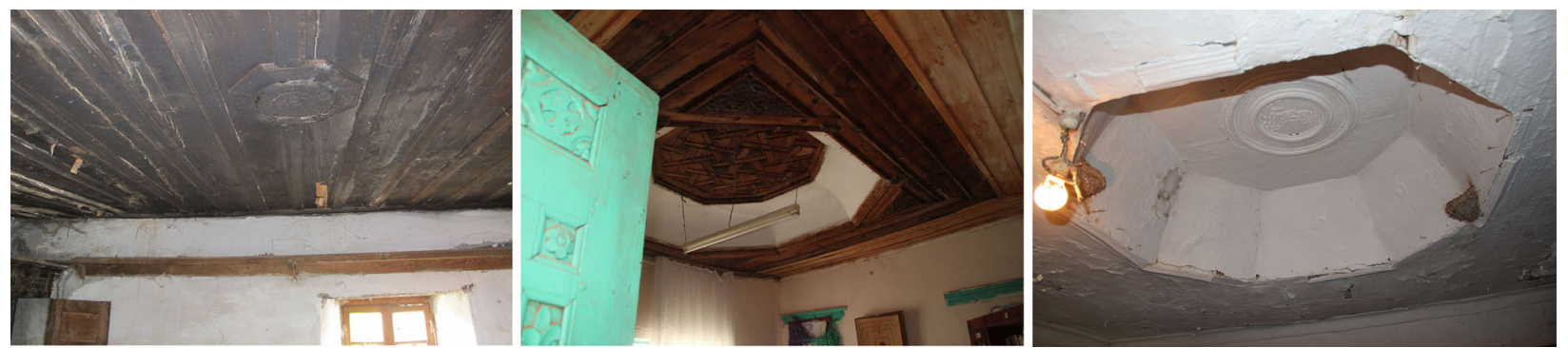

Figure 22. Protruding tavan göbeği (left), embedded tavan göbeği covered with wooden elements (middle) and embedded tavan göbeği covered with plaster and whitewash (right).

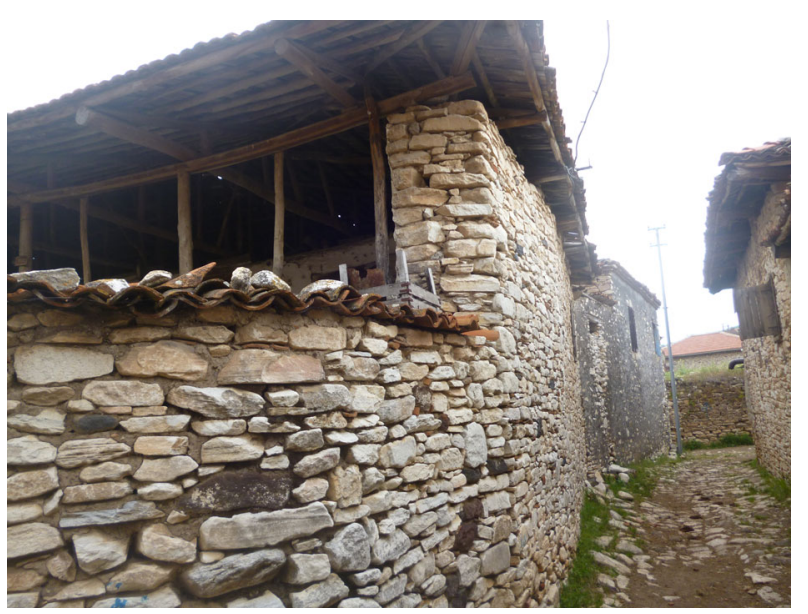

Figure 23. Roads bordered with thick stone masonry walls of the houses and courtyards.

observed in one of the rooms of RG's house, in the Rum neighbourhood (Fig. 22, right). In this case, the ceiling included tavan göbe $\breve{g} i$ and it was completely covered with lime plaster and whitewash. Additionally, it included a grape figure within the circular ornamentation, which was made of gypsum.

\section{CONSTRUCTION MATERIALS AND TECHNIQUES}

The walls were mainly constructed from köfeki, a volcanic stone obtained from the extinct volcanos around the area, such as Divlit, and white marble, obtained from the ancient lime quarry located near the settlement (Figs 1 and 4). Following the population exchange, materials from deserted Rum houses and stones were used for the construction of new buildings. For the lime plaster, fine sand was obtained from the beds of the Gediz and Selendi Rivers, and lime dust was transported from the ancient lime quarry (Figs 1 and 4).

Timber was used for the floors and roofs, the timber frame walls of the upper floors, bond beams of the stone masonry walls and other architectural elements. OG, the last stonemason of Gölde, stated that sources of wood in Gölde were quite limited; the available timber was unsuitable for construction and was used only as firewood. ${ }^{44}$ Wood for construction was obtained from Kavacık and Kula (Fig. 1).

Although stone was used for the ground-floor walls, a timber-frame system was used on the upper floor(s). The timber frame was infilled with rubble stone, brick and/or mortar. A timber-frame system without the use of an infill (bagdadi) was also observed in a few of the abandoned Rum houses.

In the majority of the houses, the exterior walls were not rendered (Fig. 23). Internally, walls were covered in a double-layer plaster that comprised a thick layer of mud plaster and a fine layer of lime plaster (Fig. 24, a). ${ }^{45}$ The mud plaster was obtained by mixing yellow sand with water and adding straw into the mixture (Fig. 24, b). The lime plaster was created 

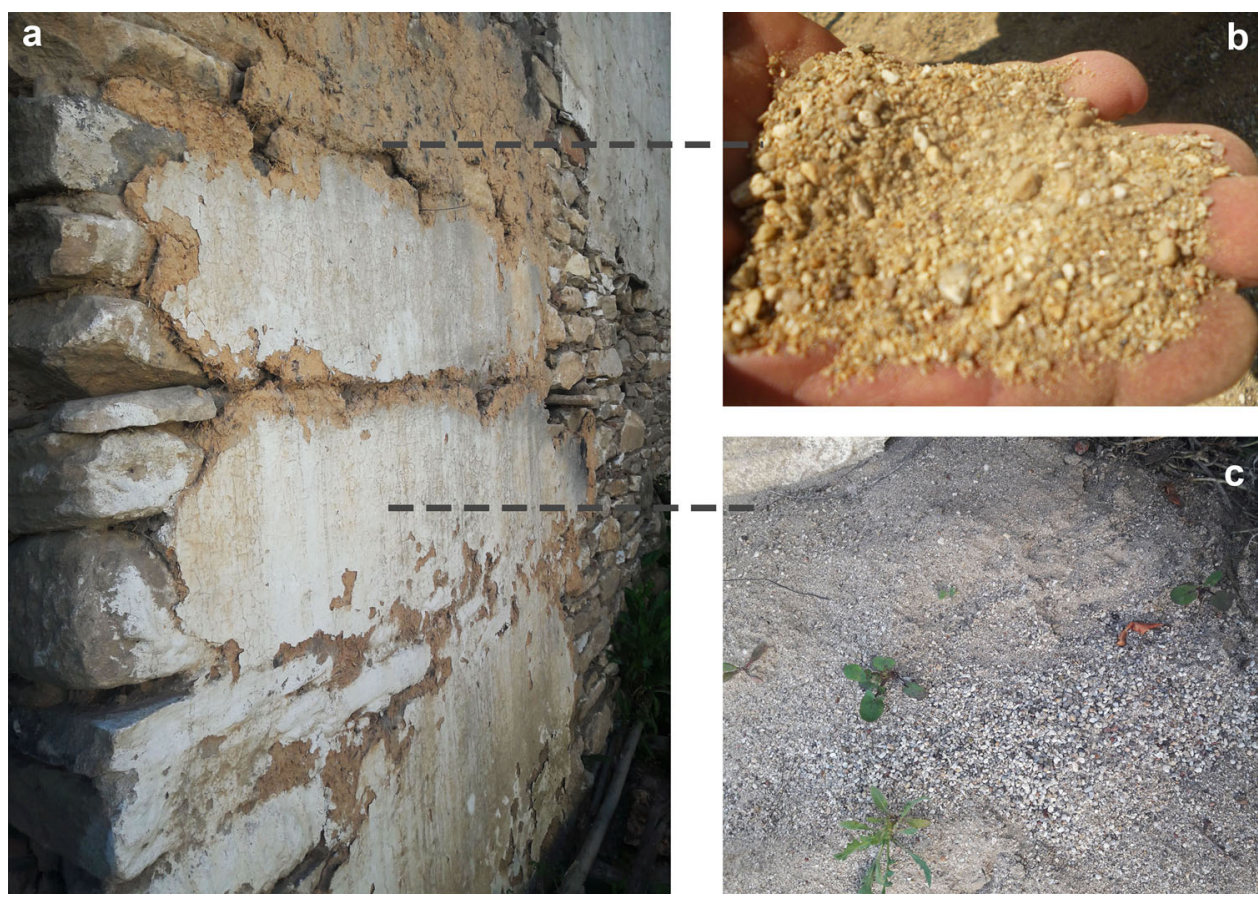

Figure 24. (a) Double-layer plaster on the wall, (b) yellow soil for the mud plaster, (c) fine sand for the lime plaster.
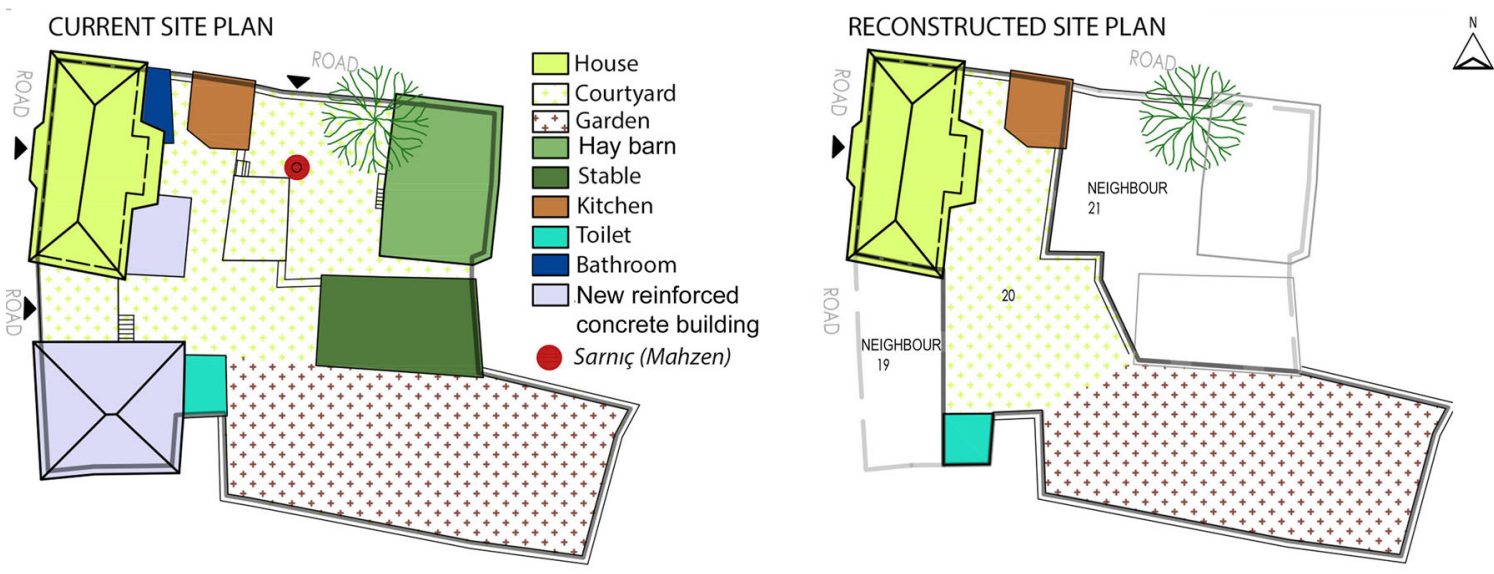

Figure 25. Comparison of current and reconstructed site plan of $R G$ 's house.
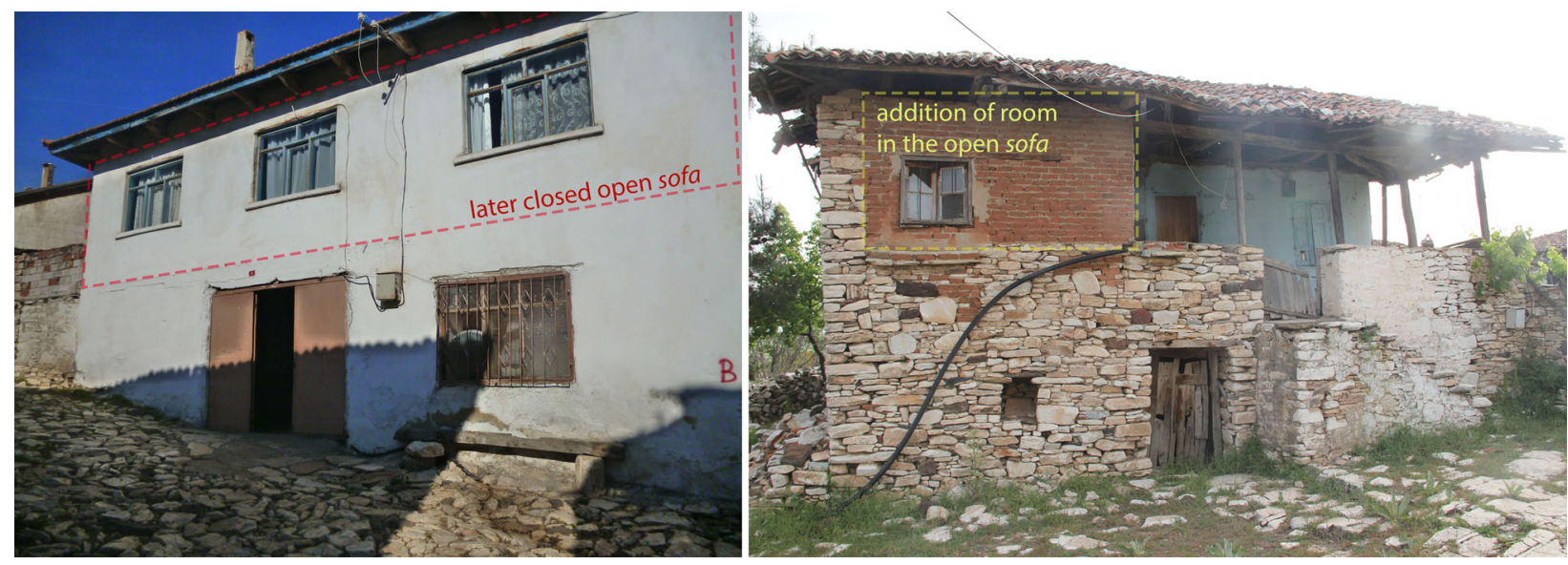

Figure 26. A house where the outer sofa was later closed (left) and the addition of a room in the outer sofa of another house (right). 

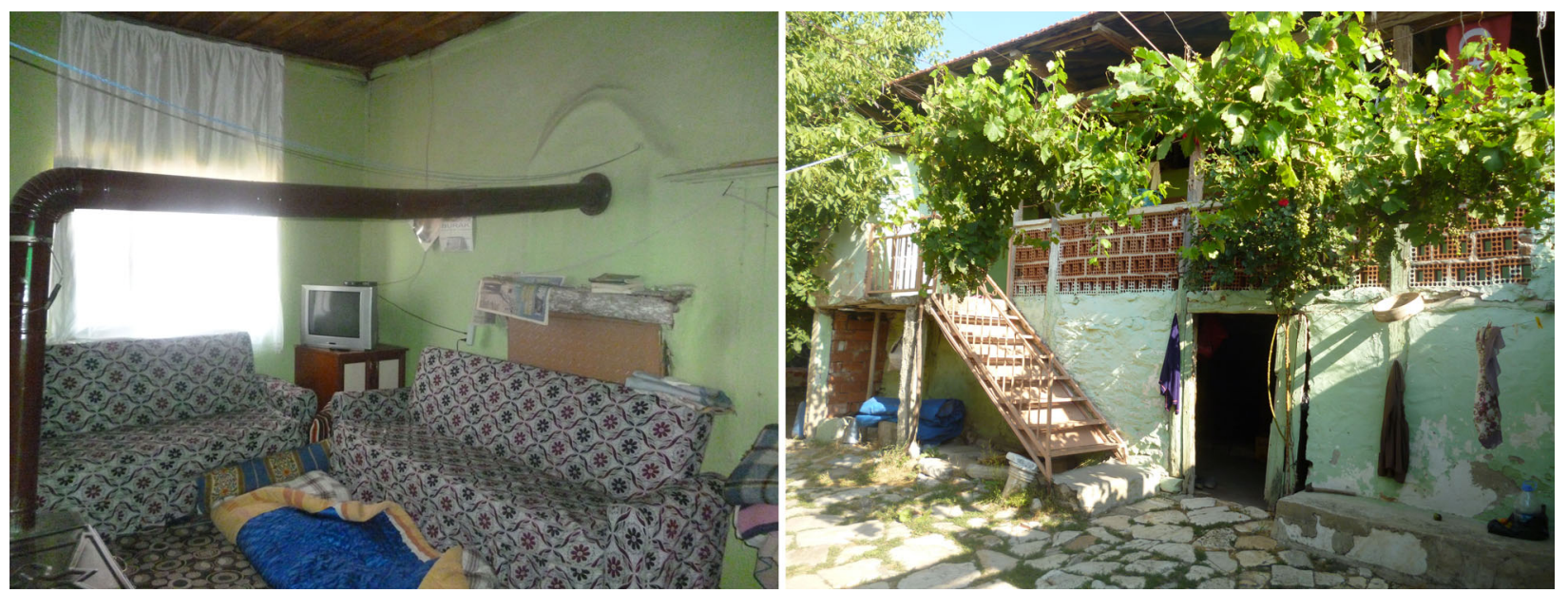

Figure 27. Closed fireplace in a room (left) and steel staircase addition in the courtyard (right).

by mixing lime, which was obtained by cooking limestone at a high temperature for three days in the furnace, with water and fine sand brought from the riverbed (Fig. 4 and 24, c). ${ }^{46}$

The floors and roof were constructed of timber. With the completion of the rough construction, master carpenters from neighbouring settlements would finish those architectural elements that required more specialist skills, such as windows and door frames, balustrades, posts and the timber floor, ceiling and roof coverings. These could be plain or contain decorative elements.

\section{ADAPTATION TO CHANGING CONDITIONS}

Gölde not only lost more than half of its population, but also its economic wealth after the departure of the Rums, who had been responsible for trade and crafts. Following the population exchange, life in Gölde evolved into a more modest one, which was based solely on agricultural production. Although the Turks occupied the majority of the houses left by the Rums, some houses were completely abandoned and have collapsed over time.

There were no major changes to the inhabited dwelling units until the 1950s when out-migration began for better economic and educational opportunities. As a result, the number of abandoned buildings dramatically increased. This period also saw a transition from the extended family to a nuclear family structure. These social and economic developments, alongside changes in needs and expectations regarding domestic comfort, resulted in some alterations to the dwelling units.

While, in the past, each room on the first floor of the house had been assigned to the nuclear family of a married son, this tradition transformed into a vertical division of the house, with a partition wall dividing the courtyard. Following this division, new buildings, such as storage units, stables and toilets, were constructed in the divided courtyards. In this way, a residential unit could be shared equally among brothers. On the other hand, the majority of the elderly population preferred to live in single-storey buildings. New reinforced concrete single-storey buildings were therefore constructed in the courtyards (Fig. 25). Additionally, some of the original storage buildings were transformed into living quarters, with alterations such as the installation of an electrical system, the creation of window openings in the walls, the replacement of the old door and the installation of a heating stove with a chimney hole in the wall. Additionally, semi-open spaces were created in the courtyards as a result of an expansion in sheep and goat farming.

Despite the construction of new living spaces within the courtyard, the original houses were still used in some of the residential lots, altered to allow for more comfortable living conditions. The main adaptations involved changes in the use of space and in architectural elements.

With regard to use of space, the sofa was completely enclosed in some houses, allowing it to be used as a seating area throughout the year (Fig. 26, left). In other houses, the sofa or iwan were partially enclosed to create an additional room (Fig. 26, right). Brick, rather than stone, was generally used for these new constructions. The new rooms are currently used as personal bedrooms, bathrooms or kitchens.

With regard to architectural elements, doors have been changed to more modest wooden doors without decoration, or PVC doors. Glazed casements have been added to the window openings, and the use of curtains has become widespread, resulting in a decline in the use of shutters. Where heating stoves are currently used in the houses, fireplaces have been closed off by putting furniture in front of them, filling them in with stone or covering them with fabric. However, the stoves are connected to the chimney of the enclosed fireplaces (Fig. 27, left). The cupboards have been transformed into permanent storage spaces for furniture that is no longer used due to the changing use of space within the house. Additionally, with the introduction of 
running water, new wet spaces were added within the house or courtyard and the gusülhane is no longer used. With the placement of modern furniture in the rooms, the original sitting elements, such as the seki and sedir, have been removed. While the majority of the stairs still possess their original characteristics, they have been strengthened or reconstructed with concrete or steel in some houses (Fig. 27, right).

\section{CONCLUSION}

This study aimed to understand the traditional rural dwellings of Gölde. Gölde was selected as a case study because of its well-preserved dwelling units that provide information about the layout and use of space in these houses before the population exchange. Although the settlement lost more than half of its population at the beginning of the twentieth century, with more than half of the houses becoming vacant, the continued occupancy in the remaining houses provides the opportunity to understand the ways in which the use of space has changed. Current members of the Gölde community also provided valuable information about way of life in these houses, both in the present and in the past.

The houses were constructed using natural building materials, using construction techniques that had developed through over time. Traditional social structures, as well as the agricultural-based economy, impacted on the layout and use of space of the house. For example, most of these dwellings had large building plots with several service spaces, such as stables and hay barns, which supported the villagers' way of life and economy.

Domestic life was more or less similar for Rums and Turks, as were the dwelling units. The outer sofa design plan, generally associated with Turkish identity, was the standard layout of the dwellings in both the Rum and Turkish neighbourhoods. While the organisation and use of domestic spaces were similar in both communities, the better economic conditions of the Rums were expressed in their buildings. Although all of the houses in the Turkish neighbourhood had an outer sofa design plan, more elaborate designs are seen only in the Rum neighbourhood. It was the Rums who introduced the inhabitants of Gölde to westernised house styles. In general, the architectural qualities of these houses reflected the economic wealth, as well as the social status, of their owners. While the house, storage unit and toilet in the courtyard were common buildings in each residential lot, wells, apilimi and shops were only observed in the Rum neighbourhood. This reflects the economic activities of the Rums, which were based on viticulture and trade.

All of the houses studied had similar architectural elements like doors, shutters, lokma parmanlık, balustrades, fireplaces, cupboards and ceilings. Even the gusülhane, which is associated with Islamic culture, is present in all of the houses. However, the architectural elements are more embellished in some houses located in the Rum neighbourhood due to the enhanced wealth of some Rum families.

While the population exchange did not change the physical environment, life in Gölde was substantially transformed. Before the population exchange, Gölde was a local centre of trade, construction activities and crafts, all run by the Rums. However, after the Rums left, the economy became entirely agricultural. The village experienced a rapid out-migration, especially after the 1970s, and most of the dwelling units were consequently abandoned. The inhabited dwelling units underwent transformations and alterations in order to meet the requirements of the remaining inhabitants.

Today, the population of Gölde is composed of mostly the elderly. The younger population does not want to live in Gölde due to the lack of jobs and educational opportunities; thus, the village faces the threat of total abandonment today. As stated by interviewee MÇ: "within 10 years at the most $[\ldots]$ there will be no people to answer your questions in this village'. ${ }^{47}$

\section{ACKNOWLEDGEMENTS}

This paper is based on a Master's thesis entitled 'Understanding Gölde (İncesu) with its Tangible and Intangible Characteristics', by Esra Eken, under the supervision of F. Nurşen Kul in the Department of Conservation and Restoration of Cultural Heritage at İzmir Institute of Technology in 2018

We would like to thank the municipality of Kula for providing documents and accommodation and the locals of Gölde for their hospitality. We also would like to thank Assist. Prof. Dr Leyla Aksu Kılıç who kindly translated the original Ottoman documents into modern Turkish.

In this study, interpretations are based on interviews with current locals in the settlement, narratives of former Rum inhabitants and observations on site. All images are copyright of the authors.

\section{NOTES}

1. Cil, "Space, Practice, Memory," 2.

2. Baykara, "19. Yüzyı lda Urla Yarı madası nda Nüfus Hareketleri," 197.

3. The original Ottoman document was translated to modern Turkish by Assist. Prof. Dr Leyla Aksu Kı lı ç from the Department of History, Ușak University.

4. Cuinet, La Turquie d'Asie, 565-9; Sami, Kamus'u Alem, 3766; Dawkins, Modern Greek in Asia Minor, 38.

5. Obtained from the Centre for Asia Minor Studies Archive.

6. Bozdağlıŏ̆lu, “Türk-Yunan Nüfus Mübadelesi ve Sonuçları,” 10.

7. Interview with IM, 12 May 2017.

8. According to the first article of the "Convention and Protocol Concerning the Exchange of Greek and Turkish Peoples" signed by Turkey and Greece on 30 January 1923, Orthodox Greeks in Turkey and Muslim Turks in Greece would be subjected to forced migration as of 1 May 1923. Those who had already migrated would not be allowed to return to the countries they came from without the permission of the Turkish and Greek authorities. With this convention, approximately 350,000 Turks and 200,000 Greeks were subjected to forced migration. Kayam, "Türk Yunan Nüfus Mübadelesi," 581.

9. Malay, "Katakekaumene'de Yerlessimler," 5.

10. Interview with EC and IG, 13 May 2017. 
11. Obtained from CAMS Archive.

12. Ibid.

13. Interview with YD, 12 May 2017.

14. Obtained from CAMS Archive.

15. On 6 January, the Teofania Festival, which was based on the baptism of Christ in the Jordan River, was celebrated by the Greeks. It took place on the last day of a twelve-day celebration period, which started at Christmas (Omilo, "The Celebration of Epiphany").

16. Obtained from CAMS Archive.

17. Ibid.

18. Interview with RG, IM, HC and HU, 12-13 May 2017.

19. Interview with IE, 12 May 2017.

20. Interview with OG, 21 July 2017.

21. Interview with HU, 13 May 2017.

22. TUIK, "Address-based Population Registration System." The numbers of men and women were provided by TUIK between 2007 and 2020.

23. Asatekin, "Understanding Traditional Residential Architecture in Anatolia," 399.

24. Obtained from CAMS Archive.

25. Interview with IM and MÇ, 12 May 2017

26. Interview with RG, 25 May 2017.

27. Interview with DB, 12 May 2017.

28. Interview with OG, 21 July 2017.

29. Obtained from CAMS Archive.

30. Interview with EÇ, IM, HU and İG, 25-6 May 2017.

31. The Sofa alt 1 is a semi-open space under the first-floor sofa (Akyüz, "Geleneksel Konut Mimarisine İlişkin Kavramlar," 38-40).

32. Kuban, Turkish Hayat House, 23; Eldem, Türk Evi Plan Tipleri, 31-90; Küçükerman, Turkish House in Search of Spatial Identity, 59

33. Eldem, Türk Evi Plan Tipleri, 16; Kuban, Turkish Hayat House, 23; Kücükerman, Turkish House in Search of Spatial Identity, 59.

34. The $\operatorname{taşl}_{1} k$ is a semi-open circulation space at ground-floor level (Akyüz, "Geleneksel Konut Mimarisine İlişkin Kavramlar," 38-40).

35. Çil emphasised a second entrance door to the house, accessed with a marble staircase, as the distinctive feature of western-style houses (Çil, "Exploring the Construction of the Identities of Kula," 179).

36. Tanyeli, "The Ottoman Period," 54.

37. The Lokma parmaklı $k$ was created by passing five or seven horizontal bars through three or four vertical bars, to create a grid that covered the whole window opening. In addition to the wooden elements in the window openings, some openings and iwans were covered by sharp, pointed iron railings.

38. Çil, "Exploring the Construction of the Identities of Kula," 58.

39. Interview with ȘT, 19 July 2017.

40. Ibid.

41. Büyükerman and Güner, Anadolu Mirası nda Türk Evleri, 123; Eliade, Dinler Tarihine Giriş, 366.

42. Arslan, "Osmanlı Mimarisinde Ahşap Tavan Göbekleri," 1.

43. Asatekin, "Understanding Traditional Residential Architecture in Anatolia," 405

44. Interview with OG, 21 July 2017.

45. Ibid.

46. Ibid.

47. Ibid.

\section{DISCLOSURE STATEMENT}

No potential conflict of interest was reported by the author(s).

\section{ORCID}

Esra Eken (iD http://orcid.org/0000-0001-5036-8979

F. Nurşen Kul (iD http://orcid.org/0000-0002-5857-1119

\section{BIBLIOGRAPHY}

Akar Tanrıver, D. S. "Kula Yakınlarında Bir Antik Kent: Maionia (Gökçeören/Menye)." In Geçmişten Geleceğe Yanı $k$ Ülke Kula Sempozyumu Bildiriler, edited by Zeki Arıkan, 197-209. Kula: Kula Belediyesi, 2006.

Akyüz, E. "Geleneksel Konut Mimarisine İlişkin Kavramlar.” Ege Mimarlık, no. 3 (1995): 38-40.

Arslan, H. "Unpublished Master's." thesis., Istanbul University, 2005. "Osmanlı Mimarisinde Ahşap Tavan Göbekleri”.

Asatekin, G. "Understanding Traditional Residential Architecture in Anatolia." The Journal of Architecture 10, no. 4 (2005): 389-414.

Baykara, T. "XIX Yüzyılda Urla Yarımadasında Nüfus Hareketleri." In Osmanlılar'da Medeniyet Kavramı ve Ondokuzuncu Yüzyıla Dair Araştırmalar, edited by T. Baykara, 195-204. İzmir: Akademi Kitabevi, 1999.

Bozdağlıŏ̆lu, Y. "Türk Yunan Nüfus Mübadelesi ve Sonuçları." Türkiye Sosyal Araştırmalar Dergisi 180 (2014): 9-32.

Büyükerman, Ö., and Ş. Güner. Anadolu Mirası nda Türk Evleri. İstanbul, 1995.

Centre for Asia Minor Studies Archive. Reference: 56gkiolde_ld1900001-1900113.

Çil, E. "Exploring the Construction of the Identities of Kula, A Place in Aegean Anatolia." Unpublished $\mathrm{PhD}$ diss., University of Michigan, 20005.

Çil, E. "Space, Practice, Memory: The Transformations of the Houses in Kula, a Town in Anatolia." 6th International Space Syntax Symposium." İstanbul 60 (2007): 1-15.

Cuinet, VLa. Turquie D’Asie; Géographie Administrative, Statistique, vol. 3. Paris: E. Leroux, 1894.

Dawkins, R. M. Modern Greek in Asia Minor: A Study of the Dialects of Silli, Cappadocia and Pharasa with Grammar, Texts, Translations and Glossory. Cambridge: Cambridge University Press, 1916.

Eken, E., and F. N. Kul-Özdemir. "Understanding Gölde (İncesu) with Its Tangible and Intangible Aspects." Unpublished Master's. thesis, Izmir Institute of Technology, 2018.

Eken, E., and F. N. Kul-Özdemir. "Yaşayan Son Taş Ustası nı n Anlatımıyla Gölde Konutu." Taç Vakfi Dergisi 12 (2019): 28-37.

Eldem, S. H. Türk Evi Plan Tipleri. İstanbul: Pulman Matbaası, 1954.

Eliade, M. Dinler Tarihine Giriş. Translated by Lale Arslan. İstanbul: Kabalcı Yayınevi, 2000.

Kayam, H. C. "Lozan Barış Antlaşmasına Göre Türk Yunan Nüfus Mübadelesi ve Konunun T.B.M.M.'de Görüşülmesi." Atatürk Araştı rma Merkezi Dergisi 9, no. 27 (1993): 581-608.

Kuban, D. Turkish Hayat House. Istanbul, 1995.

Küçükerman, Ö. Turkish House in Search of Spatial Identity. Turkish Touring and Automobile Association, 2007.

Malay, H. "Katakekaumene'de Yerleşimler, Yerel Dinler ve Tapım Merkezleri." Geçmişten Geleceğe Köprü Yanı $k$ Ülke Kula Sempozyuтu, 1-3 Eylül 2006, Kula Bildiriler, edited by Zeki Arı kan, 1-32. Manisa: Kula Belediyesi, 2006.

Ocak, MehmetMasum. “19. Yüzyılın İkinci Yarısında Kula Kazası nda Sosyal ve İktisadi Durum: Şer'iye Sicilleri ve Arşiv Kaynakları Işı ğı nda Bir İnceleme." Unpublished PhD diss., Dokuz Eylül University, 2014.

Oikonomou, A., and F. Bougiatioti. "Architectural Structure and Environmental Performance of the Traditional Buildings in Florina." Building and Environment 46, no. 3 (2011): 669-689.

Omilo, nd. "The Celebration of Epiphany (of Lights) - Greek National Holiday." Accessed May 20, 2018. https://www.omilo.com/ celebration-epiphany-lights-greek-national-holiday/.

Özkeçeci, İ., S. N. Gül Durukan, and H. Alacalı. "17-18. Yüzyı llardaOsmanlı Dönemi Konut Mimarisinde İç Mekan Tavan Süslemelerine Genel Bir Bakış." Ínsan ve Ínsan Dergisi 17, (2018): 214-232. 
Öztürk, A. N. Kula: Katakekaumene (Yanık Yöre): 200 Yıl Önce Strabon'un Adını Koyduğu Yöre. İzmir: Öğrenci Basımevi, 1986.

Sağı roğlu, Ö. "Characteristics and Construction Techniques of Akseki Bucakalan Village Rural Dwellings." International Journal of Architectural Heritage 11, no. 3 (2017): 1-55.

Şahin Güçhan, N., and V. B. Kurtuluş. " "Characteristics of Rural Architecture and Its Use in the Çomakdağ Kı zı lağaç Village, Turkey." Vernacular Architectur 51, no. 1 (2020): 50-77.

Sami, S. Kamus'u Alem. vol 5. İstanbul: Mihran Matbaası, 1896.
Tanyeli, U. "The Ottoman Period from the Beginning to the Age of Modernization 1300-1800." In Housing and Settlement in Anatolia: A Historical Perspective, edited by Y. Sey, 214-220. İstanbul: Tarih Vakfi, 1999.

TUIK (Turkish Statistical Institute). "Address-based Population Registration System.” Accessed September 8, 2021. https://biruni. tuik.gov.tr $/$ medas $/$ ?kn=95\&locale $=$ tr.

Uzunçarşıllı, İH. Anadolu Beylikleri ve Akkoyunlu, Karakoyunlu Devletleri. Ankara: Türk Tarih Kurumu Basımevi, 1988. 